\title{
THE UNIVERSITY OF MANITOBA
}

AVAILAUILITY UF ANINO ACIUS FROM

BARLEY, WHEAT, TRTTICALE ANI SOYBEAN MEAL

FOR GROTING PIGS

by

VILLEM CORNELIS SAUER

\begin{abstract}
A THISIS
SUBMITTEI) TO TIF FACULTY OF GRAIDUATE.

STUDIES TN PARTIAI FULFILINANT OF TIE

RLQUIIREMENTS FOR THE DEGREE

OF MASTER OF SCITNCE.
\end{abstract}

DEPARTIENT UF ANIMAI SCIENCE

WINATPEG, MANTTOBA

January, 1972

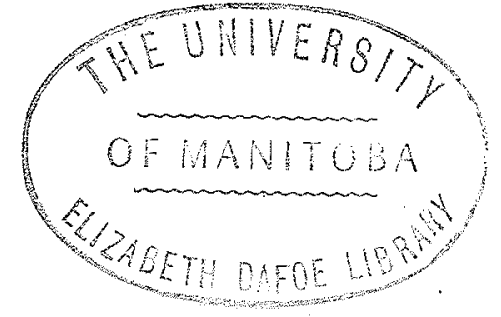


AIBSTIACT

The biolorical availability of sixteen anino acids from barley, wheat, triticale and soybean meal to Managra barrow's weighing $10 \mathrm{~kg}$ or $30 \mathrm{~kg}$ was determined.

For the $10 \mathrm{~kg}$ pigs, the true nitrogen

digestibility decreased from $9 ! .7$ to 92.0 to 90.9 and to 85.8\% for soybean meal, triticale, wheat and for barley respectively, and from 91.6 to 89.6 to 88.1 and to 83.7\% for the 30kg pigs. Generally, the true availability of each essential amino acid determined decreased from soybean meal to triticale to wheat and to barley.

The true availabilities of the essential anino acids of the cereal grains could be classified in four groups fron low to high availability : 1) lysine, which was least available $(p<.05)$, its availability being $86.3,80.8$ and $77.1 \%$ for the 1 igrhter pigs and 77.5 .67 .3 and 65.0; for the heavier pigs in triticale, wheat and barley respectively, 2) Isoleucine, methionine, threonine and valine of which the availabilities varied between $90.3-92.4,87.3-89.8$ and $84.7-87.6 \%$ for the 1ighter pigs and between 86.8-87.7.85.4-836.1 and 81.584.6\% for the heavier pigs fed triticale, wheat and barley respectively, 3) Leucine, its availability beingr 93.7.91.2 and 88.7\% for the 1 irhter pirs and 91.3 , 89.8 and $87.6 \%$ for thr heavier pirs led triticale, wheat 
and barley respectively, 4) Arginine, histidine and phenylalanine were the most available essential amino acids. The availabilitics of these amino acids varied between 93.8-9!1.5,92.4-94.7 and 90.1-93.2\% 5or the 1 ighter pigs and between 93.3-94.1,91.6-93.1 and 89.590.1\% for the heavier pigs fed triticale, wheat and barley respectively.

Methionine was the least available essential amino acid in soybean meal for the heavier pigs, namely $86.3 \%$ However, its availability was not significantly different $(\mathrm{p}<.05)$ from that of valine, threonine and lysine which were 90.9, 91.0 and $91.2^{c}$ respectively. No simnificant differences (!<.05) in amino acid availabilities from soybean meal were detected for the lighter pigs. The true availabilities varied between 94.0 and $98.4 \%$

For the non-essential amino acids, alanine was the least available and giutamic acid, proline and serine were the most available for all feeds tested. 
TABLE OF CONTEITS

page

ACKNOWLEDGEMENTS ...................... 1

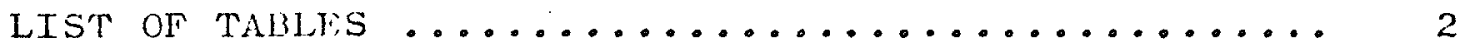

LIST OH FIGURES .......................

LIST OH APPENDICES $\ldots \ldots \ldots \ldots \ldots \ldots \ldots \ldots \ldots \ldots \ldots$

INTIROUUCTION $\ldots \ldots \ldots \ldots \ldots \ldots \ldots \ldots \ldots \ldots \ldots \ldots \ldots \ldots$

REVIET of THE LITERATURE .................. 9

The efrect of dry matter intake and digestibility on the metabolic fecal

nitrogren and amino acid excretion .........

The effect of source and lovel of protein on the metabolic fecal nitrogren and amino acid excretion ......................... 12

Dilution of dietary amino acids by endogenous amino acids in intestinal contents and feces ..................... 14

The influence of microflora on amino acid availability ...................... 19

Factors determining lysine availability and its deternination in different foodstutes by

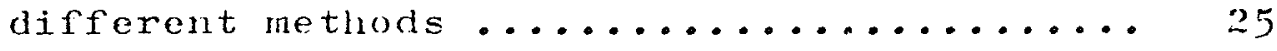

MATERIALS AND METHODS $\ldots \ldots \ldots \ldots \ldots \ldots \ldots \ldots \ldots \ldots \ldots \ldots \ldots \ldots \ldots$

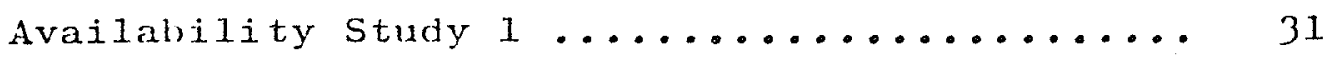

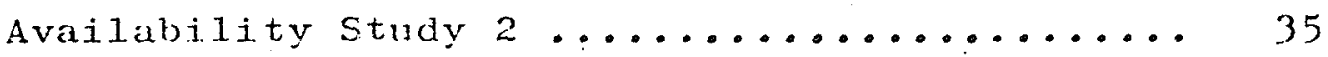

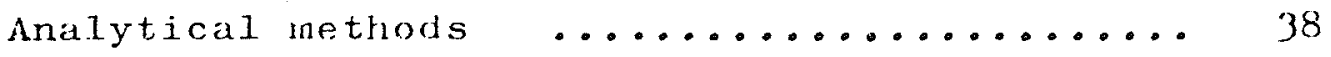

REStLTS ............................... 40

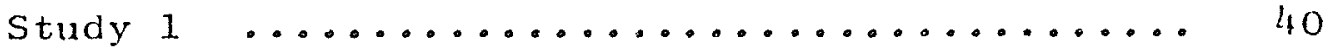

1. Apparent and true availability between test diets

a) Apparent availability ........... 42

b) True availability $\ldots \ldots \ldots \ldots \ldots . . . .45$

2. Apparent and true availability within test dicts

a) Apparent availability ........... 46

b) True availability $\ldots \ldots \ldots \ldots \ldots \ldots \ldots$ 
RESULTS (continued)

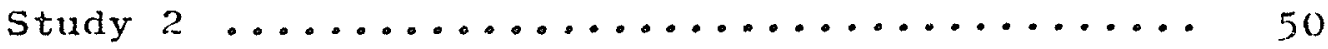

1. Apparent and true availability between test diets

a) Apparenit availability ........... 52

b) True availability $\ldots \ldots \ldots \ldots \ldots . \ldots 53$

2. Apparent and true availability within test diets

a) Apparent availability .............. 54

b) True availability $\ldots \ldots \ldots \ldots \ldots \ldots$

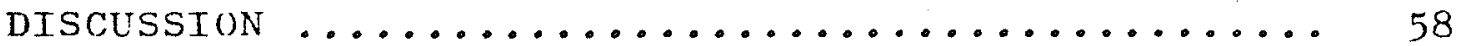

Comparisons between the dietary and fecal

amino acid levels when expressed as $g$

amino acid/16 $\xi$ nitroren and its

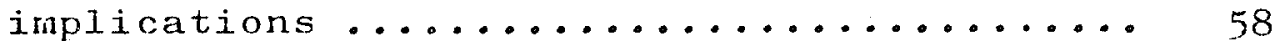

Comparisons between the dietary aruino acid availabilities when the dry matter intake or excretion of the protein-free diet is made equal to that of each test diet ......... 70

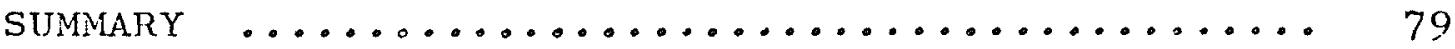

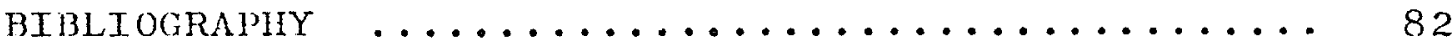

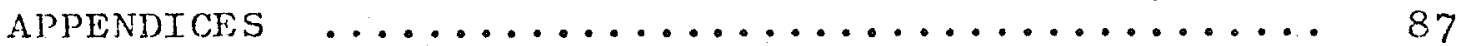




\section{ACKNOWLEDGEMENTS}

The author is very grateful to

Dr S.C. Stothers for his assistance, guidance and advice, as well as his patience throughout the course of this study.

Appreciation is also expressed to

Mr Peter Mills for his technical assistance with amino acid analyses.

Furthernore, the author is indebted to his parents for providing personal financial assistance when necessary and to his wife for her encouragement and occasional assistance towards the completion of this thesis. 
LIST OF TAJBLES

Table

Page

1. Metabolic fecal nitrogen excretion as influenced by ciry matter intake and digestibility and its relation to dietary fecal nitrogen in growing rats when these were fed a $10 \%$ protein diet of which the true nitrogen

digestibility varied between 98 and $80 \%$.. 11

2. Formulation and composition of diets for amino acid availability studies........ 33

3. Mean and standard error of the dry natter and nitrogen intake, excretion and digestibility for the test and protein-

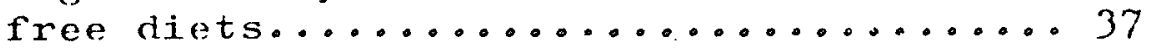

4. Comparison of apparent and true availability between test diets in

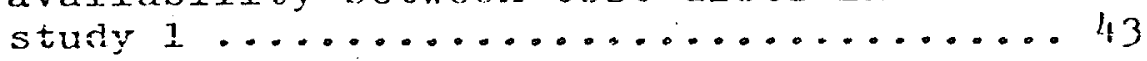

5. Comparison of the mean apparent amino acid availabilities within the test

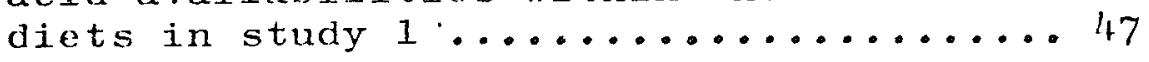

6. Comparison of the mean true araino acid availabilities within the test diets in study $1 \ldots \ldots \ldots \ldots \ldots . . \ldots . . . . . . .48$

7. Comparison of apparent and true availability between test diets in

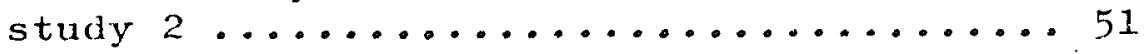

8. Comparison of the mean apparent amino acid availabilities within the test diets in study 2 (means for eight pigrs) ........ 55

9. Comparison of the mean true amino acid availabilities within the test diets in study 2 (means for eifht pirs) .......5 56

10. Correction factors for equal dry rater excretion and consumption of the proteinfree and test diet and the corrected nitrogen digestibilities and lysine availabilities .................. 59 
11. Average true amino acid availability (\%) corrected for equal dry matter excretion and consumption of the protein-free and test diet in study $1 \ldots 60$

12. Average true amino acid availability $\left(\begin{array}{c}c \\ 0\end{array}\right)$ corrected for equal dry matter excretion and consumption of the protein-free and test diet in study $2 \ldots 61$

13. Cumparison of the corrected metabolic fecal anino acid excretion $(g)$ from the lifhter (study 1 ) and heavier pigs

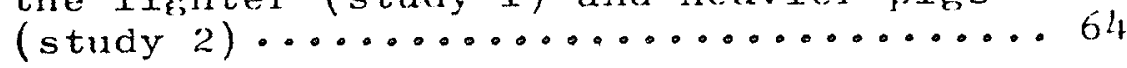

14. Comparison between the dietary amino acid levels $(\mathrm{g} / 16 \mathrm{gN})$ and the apparent or true fecal amino acid levels for study 1.71

15. Comparison hetween the dictary amino acid levels ( $\mathrm{g} / 16 \mathrm{GN})$ and the apparent or true fecal amino acid levels for study $2 \ldots .72$ 


\section{LIST OF FIGURES}

Figure

Page

1. Metabolic cages for digestibility trials with swine

2. Experimental designs for study 1 and 2 


\section{LIST OF APJENHTCES}

\section{Appendix}

Table

Page

1. Analysis of variance between treatments for study 1: Nean squares for apparent amino acid availabilities and apparent nitrogen and dry matter

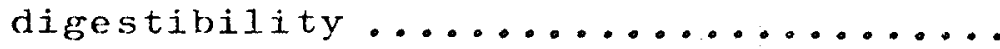

2. Analysis of variance between treatments for study 1: Mean squares for true anino acid availabilities and true

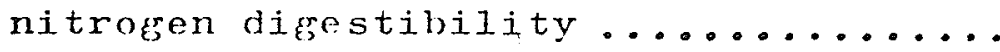

3. Analysis of vaniance between treatments for study 2: Mean squares fొor apparent anino acid availabilities and apparent nitrogen and dry matter

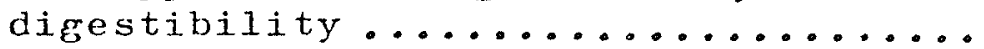

4. Analysis of variance between treatments for stuciy 2: Mean squares for true amino acid avaibabilities and true nitrogen digestibility ...........

5. Analysis of variance within treatments for study 1: Mean squares for true and apparent amino acid availabilities

6. Analysis of variance within treatments for study 2: Mean squares for true and apparent amino acid availabilities 92

7. Mean and standard error of the apparent availability of anino acids in study 1 as influenced by the type of diet.....

8. Mean and stanclard error of the true availability of amino acids in study 1 as influenced by the type of diet ..... 94

9. Mean and standard error of the apparent availability of amino acids in study 2 as influenced by the type of diet....

10. Mean and standard error of the true availability of amino acids in study 2 as influenced by the type of diet..... 
Appendix

Table

Page

11. Mean and standard error of the anino acid excretion (ह) by the pigs in study 1 as influenced by the type of

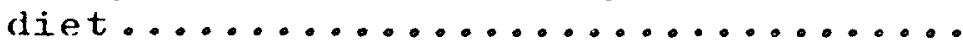

12. Mean and standard error of the amino acid excretion ( $\varepsilon$ ) by the pigs in study 2 as influenced by the type of

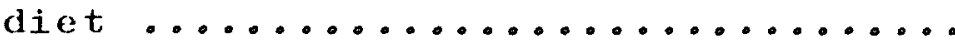

13. Triticale repeat experiment of study 1: Mean and standard error of the true and apparent amino acid availability and excretion of amino acids by the

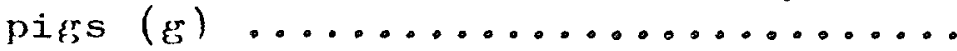

14. Mean apparent and true essential amino acid availabilities, nitrogen and dry matter digestibility between the test periods in study $2 . . . \ldots \ldots \ldots . . . . .100$

15. Comparison between the dietary amino acid levels (g anino acid $N / 16 \mathrm{~g} N$ ) and the apparent tecal amino acid levels

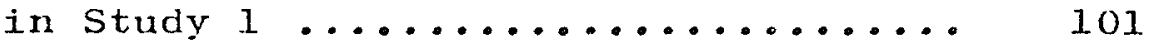

16. Comparison between the dietary anino acjd levels ( $\mathrm{g}$ amino acid $N / 16 \mathrm{~g} N$ ) and the apparent fecal amino acid levels in

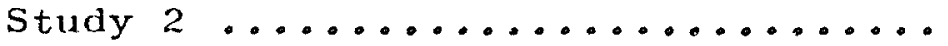




\section{INTRODIJCTION}

Since the development of the column chromatographic method for anino acid determinations it has become possible, on a more extensive basis, to consider not only protein as the unit in nutrition but rather the individual amino acid.

Amino acid levels determined after acid hydrolysis of foods predict their potential value. However, their kinetic value, i.e. their availability to the animal may be significantly less for some foodstuffs.

The term availability has been defined by de Muelenaere et al. (1967) as "that portion of amino acids present in a protein which is used for growth, development and maintenance of an animal in so far as it is dependent on the digestibility of the protein, presence of peptide linkages that are resistant to the digestive enzymes, digestive enzyme-inhibiting substances and rate of release of the amino acids in the intestinal tract". Amino acid availability defined as such may be determined by measuring the amount of inisested amino acjes excreted in the feces of test animals fed different foodstuffs according to the fecal analysis method as was developed by Kuiken and Lyman (1948).

$$
\text { Lysine is the indispensable amino acid that is }
$$

most limiting in many foods of plant origin, especially in cereal grains, which represent the major source of 
protein for most of the "underdeveloped" countries. Consequentiy, particular attention has heen friven to deternination of lysine availability. It may very well be that lysine is liniting in these foods due to its low availability. In view of possible Iysine supplementation to foods in which lysine is liniting it vill be of utmost. importance to obtain an accurate estimation of its availability in these foods.

In view of the extensive use of ceroal frrains in swine rations, the objective of this study was to determine in the pig the apparent and true arino acial availabilities from different cereal graius relative to those of soybean meal. In addition, similarities between the functions of the digestive tracts of pig and man enable us to extrapolate data obtained from experimental. work with pigs and compile results which wight be applied to man. Furthermore, amino acid availabilities were assessed for groups of pigs weighing $10 \mathrm{~kg}$. and $30 \mathrm{~kg}$. at the start of the experiment to determine if an age ractor was involved in availability of amino acids. 


\section{REVITW OF THE LITERATTRE}

Amino acid availability may be determined by measuring the amount of ingested anino acids excreted in the feces of test animals fed different foodstuffs. At least two major problems are inherent in this method for determining amino acid availability of foodstufis:

1) The estimation of the contribution of the endofrenous amino acids to the andino acids derived fincule tost diet in the feces, and 2) the offect of the intestinal microflora, especially those of the larere intestine, on amino acid availability. An attempt is made in this review to determine to what extent these problems affect anino acid avajlability as deternined by the fecal analysis method according to Kuiken and Lyman (1948). A special chapter is devoted to lysine availability per se since it is the most limiting essential amino acid in many foods of plant origin, especially in cereal grains.

The effect of ary mattes intake and digrestibility on the metabolic focal nitrogen and amino acid excretion

It is conceivable that the amount of netabolic fecal nitrogen (N) excreted varies with the type of diet fed. This diet-metabolic fecal $N$ interaction is to be kept in mind when deternining the true $N$ disestibility of a particular foodstuff. The lovel of dietary liber, in particular, has been studied regarding its effect on loss of endogenons $\mathrm{N}$. 
Meyer (1956) carried out $N$ balance studies involving 48 growing, rats which were pạir-red a $0,5,15$ or 30\% cellulose diet. Cejlulose was added at the expense of the basal ration, so that the ratios of sucrose and fat to protein, vitamins and minerals remained constant. The basal ration contained $86.8 \%$ sucrose and $4.0 \%$ defatted whole-egg protein. There was no influence of fiber intake on endogenous urinary $N$ excretion. Fach added increment of cellulose increased total fecal $N$ excretion, although its concentration decreased in the feces. Fecal $\mathrm{N}$ concentration and either the cellulose intake or indigestible dry matter of the feces were inversely related but less variation was present rhen netabolic fecal $N$ concentration was related to the indigestible dry matter by the regression equation $Y=3.1+115.5 \cdot \frac{1}{\mathrm{X}}$ in which $\mathrm{Y}$ is the metabolic fecal $\mathrm{N}$ in milligrams per gram of fecal dry matter (fecal $N$ concentration) and $X$ is the percentage of indigestible dry matter in the diet. The total metabolic recal $N$ excretion has been computed, according to the equation above, under conditions of varying dry matter intake $(2-6$ g) and dry matter digestibility $(80-95 \%)$. The diet was assumed to contain $10_{j}^{c}$ protein of which the true $N$ digestibility varied from 80 to $98 \%$ and the fecal $N$ derived from dietary $N$ has been indicated for comparative purposes (Table 1). The calculations show that the contribution 
TABLE 1. Metabolic fecal nitroren excretion as influenced by dry matter intake, digestibility and its relation to dietary fecal nitrogen in Erowing rats when these were fed a $10 \%$ protein diet of which the true nitrogen difestibility varied between 98 and $80^{4}$

\begin{tabular}{|c|c|c|c|c|c|c|c|}
\hline \multirow{2}{*}{$\begin{array}{l}\text { Dry } \\
\text { matter } \\
\text { intake } \\
(\mathrm{g})\end{array}$} & \multirow[t]{2}{*}{$x^{1}$} & \multirow[t]{2}{*}{$\mathrm{Y}^{1}$} & \multirow{2}{*}{$\begin{array}{l}\text { Total } \\
M \cdot F \cdot N \\
(m g)\end{array}$} & \multicolumn{4}{|c|}{$\begin{array}{l}\text { Dietary fecal nitrogen } \\
\text { (mg) at varying true } \\
\text { nitrogen digrestibility }\end{array}$} \\
\hline & & & & 98.0 & 95.0 & 90.0 & 80.0 \\
\hline \multirow{3}{*}{2.0} & 5.0 & 26.1 & 2.6 & 4.0 & 10.0 & 20.0 & 40.0 \\
\hline & 10.0 & 14.6 & 2.9 & 4.0 & 10.0 & 20.0 & 40.0 \\
\hline & 20.0 & 8.9 & 3.6 & 4.0 & 10.0 & 20.0 & 40.0 \\
\hline \multirow{3}{*}{4.0} & 5.0 & 26.1 & 5.2 & 8.0 & 20.0 & 40.0 & 80.0 \\
\hline & 10.0 & 14.6 & 5.8 & 8.0 & 20.0 & 40.0 & 80.0 \\
\hline & 20.0 & 8.9 & 7.1 & 8.0 & 20.0 & $i \neq 0.0$ & 80.0 \\
\hline \multirow{3}{*}{6.0} & 5.0 & 26.1 & 7.9 & 12.0 & 30.0 & 60.0 & 120.0 \\
\hline & 10.0 & 14.6 & 8.8 & 12.0 & 30.0 & 60.0 & 120.0 \\
\hline & 20.0 & 8.9 & 10.7 & 12.0 & 30.0 & 60.0 & 120.0 \\
\hline
\end{tabular}

$1 \mathrm{Y}=3.10+115.45 .1 / \mathrm{X}$ in which $\mathrm{Y}$ indicates the metabolic fecal nitrogen (M.F.N.) in milligrams per gram of fecal dry matter and $X$ the percentage of indigestible dry matter in the diet (Neyer, 1956). 
of the metabolic fecal $N$ to the total amount of fecal $N$ is relatively small when the true $N$ digestibility of a protein is $90 \%$ or lower. Apparent and true amino acid availability should not differ very much in this case. However, it would be advisable to formulate a proteinfree diet in such a manner that it contains an equal amount of indigrestible dry matter as the diet for which one determines the true $N$ digestibility and the true amino acid availabilities. This may be achieved by including a certain amount of fiber in the protein-free diet. It is especially important to take this precaution when the test protein is highly digestible. The test animals should also be pair-fed the test and proteinfree diet in order to guarantee equal dry matter intake.

The effect of source and level of protein on the metabolic fecal nitrogen and amino acid excretion

Mitchell and Bert $(1954)$ reviewed the effect of the source of protein on the output of metabolic fecal $N$ and concluded that the inclusion of different protein sources in a diet did not appreciably increase or decrease its output.

Snook (j.965) studied the effect of source and level of protein on the content of proteolytic enzymes in the pancreas. As compared to casein, a protein-free diet depressed and whole-egg protein elevated the pancreatic 
content of chymotrypsinogen and trypsinogen. Both zymogen levels were increased in the pancreas when a diet containing $30 \%$ casein was fed to the rats as compared to a $15 \%$ casein die.t:

Data compiled by Nasset (1965) show that a total of 64 to $263 \mathrm{k}$. of protein, derived from digestive secretions, are secreted daily in the adult man. However, protein derived from pancreatic juice makes up only 12\% of this fraction. The main protein fraction seems to be derived from intestinal juice which amounts to about $75 \%$. This fraction does not present much proteolytic activity and it seems therefore unlikely that a specific response as to source and level of dietary protein is of any physiological or nutritional importance as in the case of the pancreatic juice. According to estimations by Snook and Meyer (1964 a, 196/ b) the activities of trypsin and chymotrypsin may account for as much as $78 \%$ of the total proteolytic activity of the digesta.

In summary, although there is a specific response to source and level of protein, this response concerns only the proteolytic enzymes from the pancreas. The protein derived from the pancreatic juice makes up only a small fraction of the total digestive secretions and it would seem therefore unlikely that it results in an increase or decrease in metabolic fecal $\mathrm{N}$. 
Protein derived from intestinal mucosal cells and mucus, that is daily delivered to-the lumen of the gut, has been estimated by Nasset (1965) to be 77 to 916 in man. This protein fraction might be called "sloughoff" protein and the extent of "slough-off" would probably be dependant on the dry matter intake and digestibility of a particular diet (the main factor being the level and intake of fiber by the animal). Rate of passago of a certain diet mirht also influence the extent of "sloughoff". This protein fraction would be expected to make up a large proportion of the metabolic fecal $\mathrm{N}$. Snook and Meyer (1964a, 1964b) found that the extent of autodigestion and reabsorption of the endogenous protein by the rat was reduced in presence of exogenous protein. Consequently, determination of metabolic fecal amino acids by feeding a protein-free diet would underestimate endogenous losses of amino acids when these estimations are used for evaluatịng the true amino acid availabilities of a particular protein or protein source. However, their work was carricd out in vitro and quantitative efrects remain to be deternined.

Dilution of dietarv amino acids by endogenous amino acids in intestinal contents and feces

Results obtained by Nasset and his co-workers (1955. 1961) have made many nutritionists and physiologists ask more questions about the determination of dietary 
amino acid availability as studied by the fecal analysis method. Nasset concludes from his experimental work that the presence of endogenous $N$ in the intestinal tract acts as a homeostatic device to prevent wide fluctuations in the amino acid mixture available for absorption and that the anino acid nixture produced during digestion remained relatively constant irrespective of the composition of the ingested protein.

Nasset (1955) fed 3 different types of test meal to dogs, which were killed 1.5 hours after feeding. The dogs were fasted 24 hours before feeding. The contents of the stomach, duodenum, jejunum and ileum were collected separately. The total mass of nitrogen in the lumen of the small intestine was about the same for egr albunen and zein but it was reduced by two-thirds after feeding a protein-free meal. Zein is virtually devoid of tryptophan and 1ysine but after ingestion of about $3 \mathrm{~g}$. of zein, $15 \mathrm{~m}$. of tryptophan and $89 \mathrm{mg}$. of lysine were found in the small intestine. Anino acid molar ratios for jejunal contents were very sinilar after feedingr egr albumin, zein and the protein-free meal.

Nasset and Ju (1961) fed radioactive casein to rats by stomach tube for one meal. The rats were sacrificed at 1,2 and 4 hours after feeding and the gastric and intestinal contents were analyzed separately. At all times they found that exogenous $N$ in the intestine was diluted 6 or 7 -fold and that the 
molar ratios of free amino acids were markedly different from those found in the ingested casein.

Results from experimental work carried out by Bergen and Purser (1968) were more or less in agreement with those of Nasset. Growing rats were fed either a. $9 \%$ casein, protozoal or bacterial protein diet for 8 days. The animals were sacrificed 2 hours after feeding and the jejunal and ileal contents were collected. The bulk amino acid composition was found to be similar regardless of the protein source fed. The dilution ratio of exogenous and endogenous $N$ for the $9 \%$ casein diet was found to be $1: 1$ and $1: 10$ in the jejunum and ileum respectively. $\quad \Lambda$ for the 9 fo bacterial protein diet, the ratios were $1: 1$ and $1: 2$ and for the protozoal diet $1: 1$ and $1: 2$ in jejunal and ileal contents respectively. A protein-free diet resulted in a lower total amount of amino acids in the gut but the relative amino acid ratios were similar to those obtained from the test diets. Tombly and Meyer (1961) demonstrated differential digestion and absorption of exogenous and endogenous protein. Rats were fed 5 levels of whole egf protein namely at $0,5,10,15$ and $20 \%$ of the diet for 1 week. They were trained to eat in 1-hour periods, 12 hours apart and were sacrificed at $1,2.5,5$ and 8 hours after feeding on the seventh day. Two peaks in nitrogen concentration occurred in the contents of the small 
intestine, one at 1 hour and the other at 8 hours after feedingr the different levels of vhole efrr protein. Tho 1-hour peak was not observed in the animals receivingr a protein-free diet and was thercifore considered to be due to the accumulation of dietary protein in the intestinal 1umen. However, the 8-hour peak was observed in rats fed the protein-free diet and was attributed to secretion of endogenous protein in response to feeding. Denton and Elvehjem (1954) observed 2 peaks in the concentration curve for amiso acids in tho portal vein following the ingestion of amino acids by dogs; the first peak at 2.5 hours, the second one at 6 hours after feeding.

Crompton and Neshein (1969) fed diets to ducks in which the protein source was either a combination of corn and soybear meal or of corn and corn gluten meal. The pattern of anino acids in segmonts more distal to tho midpoint of the small intestine did not reflect the dietary amino acid pattern as well as that in upper portions sugrestingr that digestion of dietary proteins occurs hefore that of endogenous protein. The dilution of dietary protein by endogenous protein was insufficient to mask the amino acia pattern of inrested protein. In their discussion it was noted that Nassct usually fasted his animals for 24 hours and then obtained samplos 1.5 hours after feeding, and it could have been possible 
that digestion and absorption had nearly been completed and that most of the remaining protein in the intestine was of endogenous origin. This would explain the high dilution of exofenous protein by endogenous protein in the experimental work by Nasset and his co-workers $(1955,1961)$.

Interpretation of the results obtained from the experimental work discussed would seem to indicate that the fecal amino acid composition from a himhly direstible protein like casein should resemble that of a proteinfree diet due to the relative high dilution of exogenous amino acids by endogenous amino acids as a result of the loiv level of indigostible protein. Findings by Carlson and Bayley (1970), who determined the amino acid availability of a 7,14 and $21 \%$ casein diet in young pigs, seem to substantiate this interpretation. On the contrary, the fecal amino acid composition from a protein with a relatively low disestibility such as protein from cereal grains would more closely resemble that of the indigestible protein portion. The availability of amino acids from proteins in so far as it is dependant on the rate of digestive release and ahsorption may be determined by the changes of free amino acid concentrations of portal blood. As was discussed, 2 distinct peaks (the first one for exogenous amino acids, the second one for endogenous amino acids) were detected in the portal 
blood of dogs that were fed a diet in which casein or an amino acid mixture made up the protein source. Simultaneous absorption of exopenous and enciofenous amino acids would likely occur when a more slowly digestible protein was fed (for exalule, a feed of which the protein digestibility would be similar to that of the endogrnous proteinl. One peak, both for exogrenous and endoprenous amino acids, would be observed in tho portal blood and changes in the levels of free amino acids would not be indicative of the exogrenous amino acids alone. Thus, changes in the levels of free amino acids in the blood plasina resulting, from the ingrestion of protein feeds, as a method for comparing the availabilities of amino acids in different feeds, would only be valid for highly digestible proteins.

The influence of microflora on amino acid availability

The use of rerm-free laboratory animals provides a means for helping to deternine the effect of the microflora on protein metabolism in the gut.

$$
\text { llarmon et al. (1968) studied the influence of }
$$

the flora on metabolic fecal $N$ excretion with selected levels of ers white protein up to $21.5 \%$ fed as a 1 iquid or dry diet. Metabolic fecal N excretion was much 1ess in germ-irce than in normal rats. Gordon and Wostmann (1960) reported lower weights of the small intestine in germ-free than in normal rats. The rate of renewal of 
the mucosa of the smill intestine was reduced in the pretnfree rat according to Abralus ot al. (1963). (iordion and Bruckner-kardoss (1961) showed that the surface area of the small intestine was about $30 ; 0$ less in frem-free than in normal rats. Thus, it seems logical that there is a lower output of metabolic fecal $N$ in the germ-free rat because of a reduced rencwal rate of intestinal mucosa and less intestinal rucosa because of a reduced intestinal surface area. However, Evrard et al. (196/) showed that trypsin and chymotrypsin, as well as other digrestive enzymes, were elevated in the cecal contents and feces of the germ-free rat. As incicated previously, the digestive enzymes make up only a small fraction of the endogrenous protein. In summary it seems that the flora, indirectly by their presence, cause a loss of endogenous protein. Harmon et al. (1968) found that the fecal N excretion (metabolic plus exogenous) of germ-free rats was about twice that of the normal rats for a $21.5 \%$ protein 1 iquid diet. The protein source was provided by hydrolyzed casein fortified with amino acirs. Levenson and Tennant (1963) found twice as much fecal $N$ in grem-free rats than in normal rats for 13,20 and $10 \%$ dietary protein levels. The source of protein was not specified. Evrard et al. (1964) obtained similar results for a $20 \%$ casein diet. Luckey (1963) and Combe et al. (1965) found about 30\% more fecal $\mathrm{N}$ in frerm-free than in normal rats. The 
results obtained, in general, indicate that there is a higher excretion of fecal $N$ in germ-iree than in nomal rats when the dietary protein level is about $20 \%$ This sems to indicate that the flora are mainly active on indigestible dietary protein. Neshein and Carponter (1967) used caecectomy as a tool for assessing bacterial activity in chicks. In chicks, as with rats, most of any such bacterial activity would be expocted to occur in the caeca. Freeze-dried cod miscle protein was found to have an apparent $N$ digestibility of 90 and $89 \%$ in intact and caecectomized chicks respectively. Heat-damared cod muscle protein resulted in a $N$ digestibility of 77 and $68^{\circ}$ for intact and caecectomized chicks respectively. Nesheim and Carpenter (1967) postulated that, as a result of microbial action on indigested protein entering the cecum, nitrogenous compounds of no nutritional value (mainly ammonia) misht be produced and then absorbed. Significant amounts of heat-damaged cod muscle protein may remain in the cecum. Findings by salter and coates (1971) support the latter postulate. proteins which reach the lower intestinal region may undergo reactions that differ from simple proteolysis and result in the absorption of nitrogrcnous compounds from the gut in forms other than the useful amino acids, as was discussed by Barnes and kwong $(196 \%)$. It may be hypothesized that significant quantities of slowly digestible proteins 
may renain indigrested in the cecum which may then be de-aminated by fermentation so that the values ror $\mathrm{N}$ digestibility aud individual anino acid availabilities can be misleadingly high. Lloyd et al. (1958) deternined protein digestibility in whole and caecectomized pirs 8 to 28 weeks of age. Mhe removal of the cecum resulted only in a silpht decroase in protein digestibility. cranwell (1968) criticizes their work because of the fact that the test diets were changed too rapidly. Hesides, no account is taken of the microbial fermentation in the remaining part of the large intestine.

Evrard et al. (1964) found that urea accounted for at 1 east $25 \%$ or the fecal $N$ in germ-free rats whereas only traces of urea were found in the feces of. normal rats. Lepkovsky et al. (1966) deternined the distribution of protein and non-protein $N$ in the cecum of grerm-free and normal rats. Protein $N$ accounted for. $20 \%$ of total. $N$ in the 5 erm-free rat whereas it accounted for $50 \%$ in the normal rat. Levenson and Tennant (1963) reported that $70 \%$ of the fecal $N$ from ferm-free and about $50 \%$ from normal rats was filterable. Increased solubility of the fecal $N$ was also subgested by the work of larmon et a1. (1967) which showed that the percent of total fecal $N$ represented by wea $N$ was greater in frerm-rree than in conventional rats while the percentarse of 
chromatographicaliy deteruined amino acids was hirher in normal rats than in germ-freo rats. In sumiry, althourh the experiments discussed were carried out under widely different experimutal combitions (ror example, different dietary levels and sources of protein and different methods for sterilization of the diets) they show that the anabolish of $N$ from dietary and/or endogenous sources into bacterial protein may be of a signiricant proportion.

Miche1 $(1961,1966)$ isolated the microbial flora from the gastro-intestinai tract of the pir. In vitro. under conditions as closely as possible resenbling the conditions in the intestinal contents, they exerted a considerable catabolic activity towards amino acids which they can deaminate and decarboxylate. Deamination occurring was principally that of anides and nonessential anino acids. Nicarboxylic amino acids decarboxylated most rapidly. Certain indispensable amino acids in particular lysine and methionine were only very slowly degraded. Maximum catabolic activity as to arginine took place in the cecum while the microbial flora capabie of degrading aspartic acid and cysteine were mainly located in the ileum. Catabolic. activity of the microflora varied considerably from pir to pig. As was shown by Larson and llili (1960) beginning with the ileum important catabolic activity 
can be detected and then from the cecum the catatnlic activity will be limited by the small amount of free anino acids. Michel (1961) showed that the colon is the main source of ammonia production, which is derived from autolysis of bacterial protein. Nost of the atimonia is absorbed.

In sumary, the microbial floma nay be active in utilizing indigestible dietary $N$ in the lower end of the gut. It is thought to accomplish this by deanination of amino acids in the ileun and cecum and by incorporation of soluble $N$ into microbial protein which partly autolyzes in the large intestine (mainly in the colon). Both events result in the production and absorption of ammonia and nay lead to overestimation of amino acid availabilities as determined by the fecal analysis method. However, the availabilities of some amino acids mirht even be underestimated. Lysine is an essential amino acid of special importance since it is limitins in many plant proteins. Anderson et al. (1958) have shown that the level of lysine is relatively high in microbial protein. lysine is not easily degraded by the flora relative to the other essential amino acids as shown in vitro by Michel (1961, 1966). Thus, 1ysine availability may be underestimated relative to the availabilities of the other amino acids when they are determined by the fecal analysis method. 
Payne et al. (1968) surgest that measuring the quantities of anino acids passing, the end of the ileuri would provide a more meaningrul comparison of arino acid availabilities than measuretuent of anino acids in the feces. Cho et al. (1971) fitted re-entrant cannulae immediately proximal to the ileocecal junction of growing pigs, which were fed a soybean meal ciet (17.8\% protein) or a rapeseed neal ilet (19.2\% protein). Time of sampling of ileal digesta, after ingrestion of the test diet, was round to influence its amino acid levels very extensively (preliminary findings). Consequently amino acid availability studies, whereby the animal is sacrificed at a certain time after ingestion of the test diet for collection of the digesta, nay be a very critical procedure. Although the use of re-entrant cannulae is not very practical for determining the amino acid availabilities of a particular test meal, a definite indication of the extent of microbial modification may be obtained in quantitative terms by comparing the levels of amino acids in ileal digesta and reces.

Factors determining lysine availability and its determination in different foodstuit's by difrerent methods Lysine is the first limiting amino acid in many roods of plant origin, especially in cereal grains. The nutritive value of cereal protein is thought to be directly related to the proportion of lysine in the 
protein molecule which has free N-amino mroups. Carpenter $(1960)$ developed a method based on the reactivity of the l-amino rroup of lysine with fuurodinitrobenzene (F)N13). The test materials are treated with acid and the resuiting F-dinitrophenyl lysine (E-DNP-lysine) is taken as a measure of the original available lysine.

Stott and Snith (1966) sugrost that "the values for FDNB-reactive lysine mirht be supposed to represent the maxinum available lysine, as hejng a determination of the lysine not rendered unavailable by bindingr of the E-amino group". Any other factor lowering the availabijity of lysine (for examplo; the overall digestibility of the protein) could be expected to influence biolo[rica] assays and give rise to a lower available lysine estimate than that given by the FDNH method. They carried out a microbiological assay using the protozoan Tetrahymena pyriformis w for rieasurement of available lysine. Their Tetrahymena estimates of available lysine for animal protein sources were similar to those obtained by the Flinb procedure for samples with higher available lysine content $(>6 \% . / 16$ g.N) but lower than FDNB estimates for samples with lower available 1ysine content $(\angle 6 \% \cdot / 16$ r.N $)$. Boctor and llarper (1968) showed a high correlation between lysine availability estimates obtained by the FoNls and the rat-grrowth assay 
method for egr albumen, beef protein and casein. However, lysine availability values obtained by the Fun method were higher than those obtained by the rat-growth assay method when these proteins were heat-treated. Ford (1964) found that the availability of lysine was low in a beef protein concentrate, whereas the FDNH method gave higher values. It seens that lysine availability values as deternined by the FloNb method correlate well with those obtained by biological methods for proteins in which lysine is of high availability. This does not seem to be true for protein in which lysine is of low availability. In this latter categrory one misht include heat-treated animal proteins and most plant proteins like those of the cereal Grains. Besides, for foodstulfs rich in carbohydrate and with a low protein content fror example, cereals), the instability of E-DNP-lysine on acid hydrolysis is a serious problem as.was shown by Carpenter and March (1961).

Hjarnason and Carpenter (1969) fed lactalbumen, of which the E-anino groups of the lysine units were propionylated, to youn: rats. A considerable quantity of E-N-propionyl-J-lysine, which is not utilized by the rat was found in the urine. Valle-Riéstra and barnes (1970) detected $E-N-g 1 u c o s e-L-1 y s i n e$ and derivatives of this compound in the urine of rats that were fed eger white protein which was heat-damaged in the presence of Flucose. Heating pure proteins (in the absence of 
reducing, sugrars) is thoukht to give rise to the

formation of cross-linkages between the li-amino groups of 1ysine and the carboxyl groups of the dicarboxylis: amino acids or their amides as postulated by Bjarnason and Carpenter (1970). Bjarnason and Carpenter (1969) found no evidence of lysine compounds being absorbed and excreted in the urine of rats that were fed heat-iraated bovine plasma albumen. Valle-Riéstra and iarnos (1970) fed heat-damamed egr white protein to rats and letected on]y insignificant amounts of lysine and/or lysine derivatives in the urine (as radioactivity recovered in the urine from dietary ${ }^{14} \mathrm{C}-\mathrm{L}-1 \mathrm{ysine}$ from egr white protein). In sumnary it seems that lysine, when crosslinked to other anino acids, is resistant to hydrolysis by the digestive enzymes. Lysine may be hydrolyzed by the digestive enzymes from the peptides and absorbed when its E-amino group is merely blocked by carbon atoms as was shorn for riucose and propionate.

The FINB procedure, as previously discussed, does not appear to be suitable for the estination of lysine availability in heat-treated proteins. Heat treatment causes the formation of cross-linkages between lysine and other auino acids (the intensity of crosslinkage formation depending on the severity of hoat treatment). In order to explain this phenomenon one might visualize situations in which the formation of 
cross-1inkages is to occur mainly on the outside of a protein molecule and that "free" peptido lysine may he trapped on the inside of this protein molecule. One would expect a low digestibility for this particular protein molecule. Trypsin, an important digrestive enzyme, does not hydrolyze peptides at the carboxyl group of Iysine units if the E-arino group of lysine is cross-jinked as was shown by Hill (1965). The Flonb method, which involves acid hydrolysis would take into account the "trapped" lysine as available whereas biological methods for measuring lysine availability would not. The FloNis method mirht overestimate lysine availability for foodstuffs in wich the lysine availability is naturally low (for example, in cereal grains) for the sane reason as for the heat-treated proteins. The availability of jysine is relatively low in cereal grains. Gupta et al. (1958) deternined the lysine availability by the rat-grrowth assay method. lysine availability was found to be 58 and 72,0 for corn and wheat flour respectively. Stott and Sinith (1966) determined the lysine availability from wheat and barley by a microbiological assay using the protozoan Tetrahymena pyriformis $W$. Lysine availability determined as such varied extensively. It ranged from 32 to 59\% in wheat and from $3 / t$ to $63 \%$ in harley. Calhoun et al. $(1960)$ deteruined the true availability of 
lysine in wheat and wheat gluten. Lysine availability in wheat grluten (99io) was found to be much hiliher than in wheat $(75 ; 0)$ as deternined by the recal analysis method. This would indicate that lysine availability is much lower from the non-gluten protein rraction than from gluten in wheat. One would expect extensive crosslinking of lysine with other amino acids in the non-gluten protein fraction of wheat. 
MTERIALS AND METHODS

Two studies were carried out lising Maniegral pjos in order to determine the biolorical availability of amino acids by the fecal analysis method from pure barley, triticale, whoat and soyboan neal (Table ?). A proteinfree diet was employed to estinate tho retabolic fecal amino acids (Table 2). Diots used wore nade into pollots of $0.3 \mathrm{~cm}$. diameter.

\section{Availability Study 1}

The rirst part of this study was carried out in

January, 1969. Four barrows from the same litter. weighing $7.3-8.8 \mathrm{kr}$. , were individually assigned to wire cages that were circular in shape (Fig. 1), as described by Be11 (19/8). Placenent of these cages an a metal table with a round hole directly under the centre of the care permitted separation of urine and feces.

The pins received a basic diet during the three day adjustment period (Tible 2). They were red at 8 a.m., $12.30 \mathrm{p.m}$. and 5.p.m. for a $30-60$ minute period. The experiment was conducted using a $4 x$ lit latin Square dosign in order to allow testing of the four different test diets

1 The breed composition of Mandrra consists of 45,0 Swedish Landrace, 20\% Wessex Saddleback, 15\% Welsh and $20 \%$ Minnesota No. 1 - Berkshire - Yorkshire - Tanworth. 


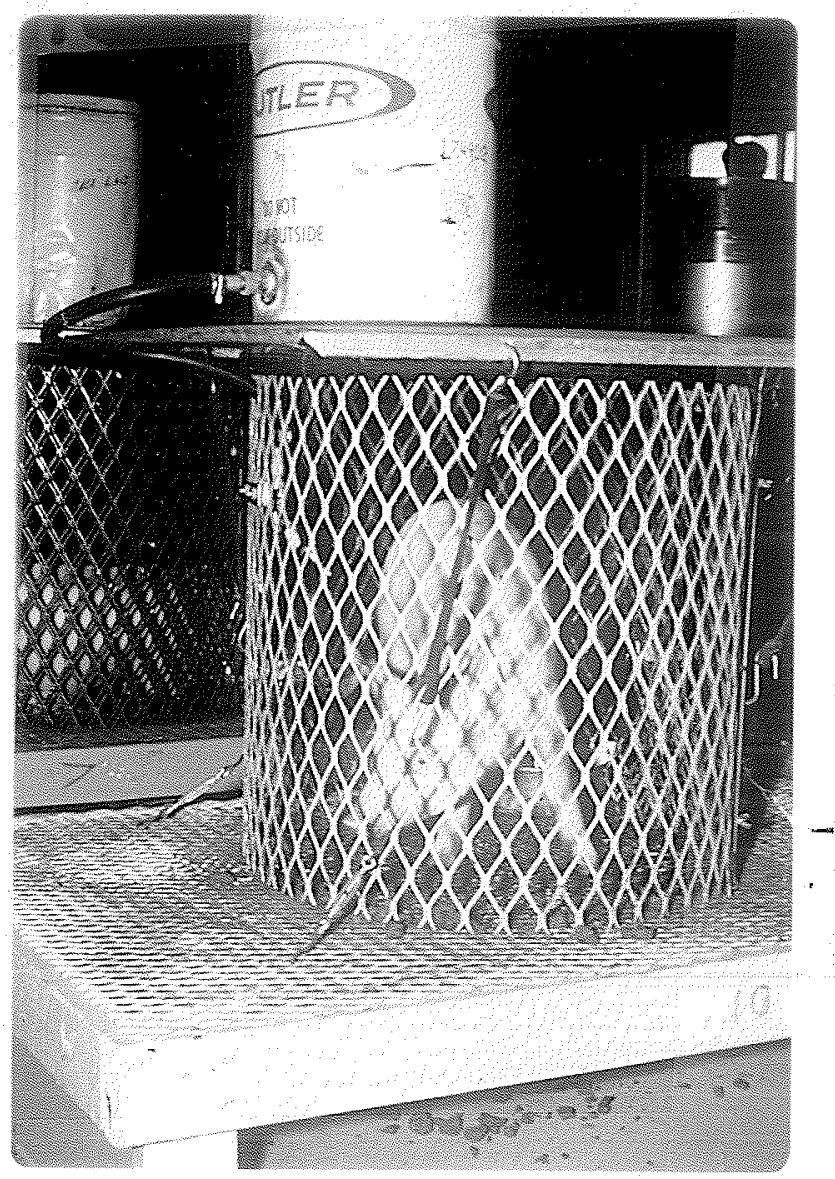

Fig. 1. Metabolic cares for direstibility trials with swine 
TABLE 2. Formulation and composition of diets for amino acid avajlability studies

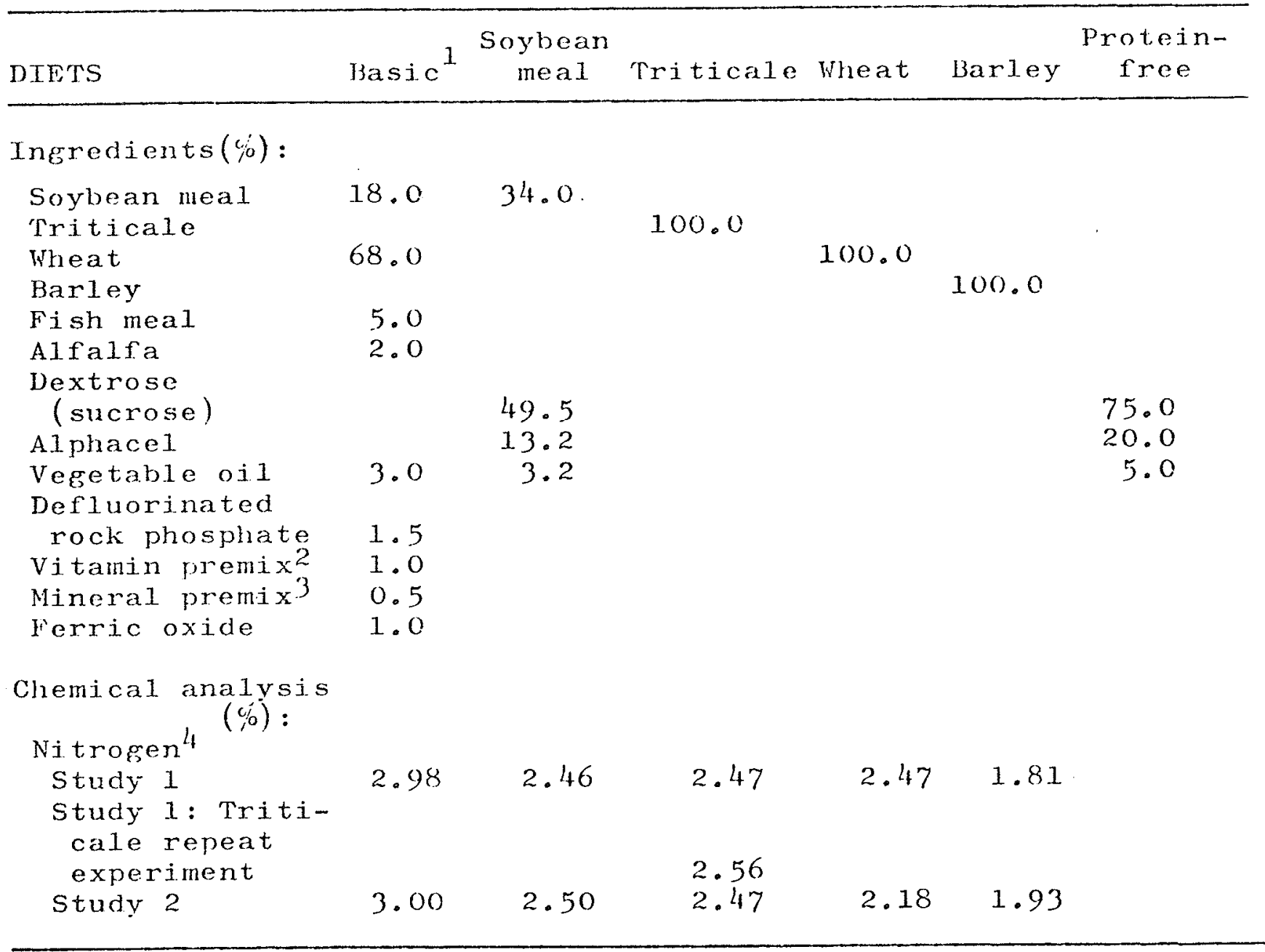

1 A "modified basic diet", containing $66 \%$ of the basic diet and $34 \%$ of the protein-free diet, was employed in study 1.

2 Contains per kr diet: vitamin A (7150IU), vitamin D 3 (818TCU), vitamin $\mathrm{E}$ (5.5IU), vitamin $\mathrm{B}_{12}$ (11 ug), vitamin $B_{58}$ premix (5.5 mer riboflavin, 11.0 mg pantothenic acid, 16.5 mg nicotinic acid, $275 \mathrm{mg}$ choline chloride), Dl, methionine (0.5\%), menacione (1. Im $)$, Santoquin (1.1mg) and penicillin-streptomycin ( 26.4 mg).

3 Contains per kg diet: manganese oxide (81.4mg Mn), zinc oxide (11 mer $/ \mathrm{n})$, ferrous sulfate $(35.2 \mathrm{mg}$ Fe), copper sulfate $(6.6 \mathrm{~m}, \mathrm{Cu})$ and iodized salt $(4.7 \xi)$.

4

Expressed as a percontage of dry matter 
by the four pigs at four different periods. The test diets were fed for one day during each period. The pigs were permitted to consume up to 600 g. of test diet each day and it was attempted to have them consume $200 \%$. at each meal. They were allowed to drink up to 200 milliliters of water before and after each meal. The basic diet gave rise to soft feces with a relatively high incidence of diarrhea, initially noted during the adjustment period. Consequently, the basic diet was diluted with the protein-free diet so that the protein content was reduced from 18.8 to $12.4 \%$. This "modified basic diet", which was fed a day berore and a day after the test diet, produced drier feces and a lower incidence of diarrhea.

One percent of ferric oxide was included in the original basic diet in order to permit easier identification and collection of frces resulting from the test and protein-free diets.

The protein-free diet was fed for one day following the feeding of the "modified basic diet" for two days, subsequent to the first test period. The pirs were fasted the noon and evening meal prior to the day they were fed the protein-free diet because of its relative unpalatability. The "modified basic diet" was fed again for one day after the protein-free diet and the 
rest of the test diet - "modified basic diet" sequence was carried out (Fis. 2).

The experiment described vas repeated in

February, 1969. Four different barrows of the same litter and of similar weights were used. The proteinfree diet, however, was fed immediately after the three day adjustment period.

In both studies it was observed that the consumption of triticale was relatively low compared to that of the other test diets (Table 3). Therefore, a separate availability study was carried out on triticale in which four litter-mate barrows were used, weighing 9.3-13.2 kg. This study was carricd out in July, 1970. Triticale devoid of ergot was fed and its consumption increased to a level similar to that for the other test diets (Table 3$)$.

\section{Availability Study 2}

This study was carried out in December, 1969.

Eight barrows from four litters, two from each litter, were subjected to similar experimental conditions as described for study 1. The barrows ranged in weight from $28.6-34.1 \mathrm{~kg}$. at the beginning of the experiment following the four day adjustment period. 
Fig. 2 Experimental desirns for study 1 and 2

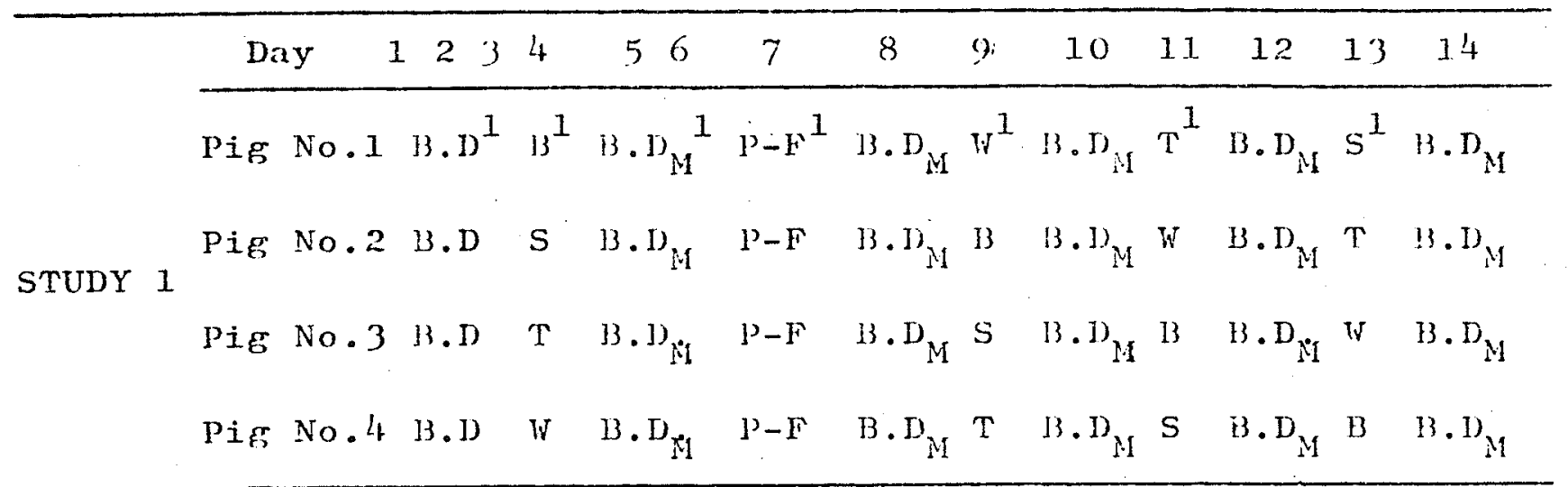

$\begin{array}{lllllllllllllllll}\text { Day } & 1 & 2 & 3 & 4 & 5 & 6 & 7 & 8 & 9 & 10 & 11 & 12 & 13 & 14 & 15 & 16\end{array}$

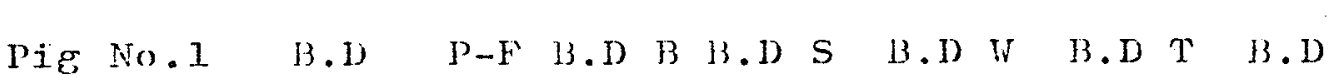

Pig No.2

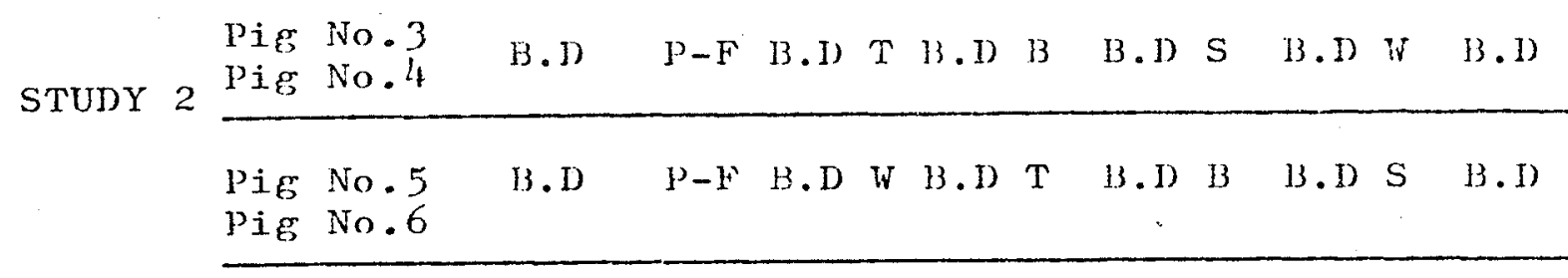

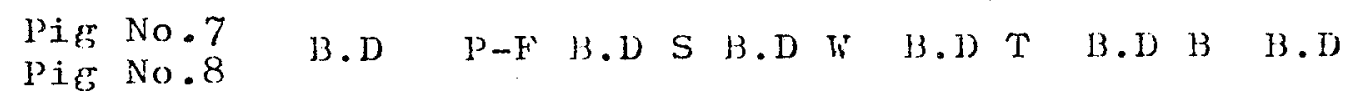

1 Basal diet (B.U); Modified basal diet (B.D. $)$; protein-frec $(\mathrm{P}-\mathrm{F})$; Harley (B); Wheat (W); Triticale (T); Soybean meal. (S). 


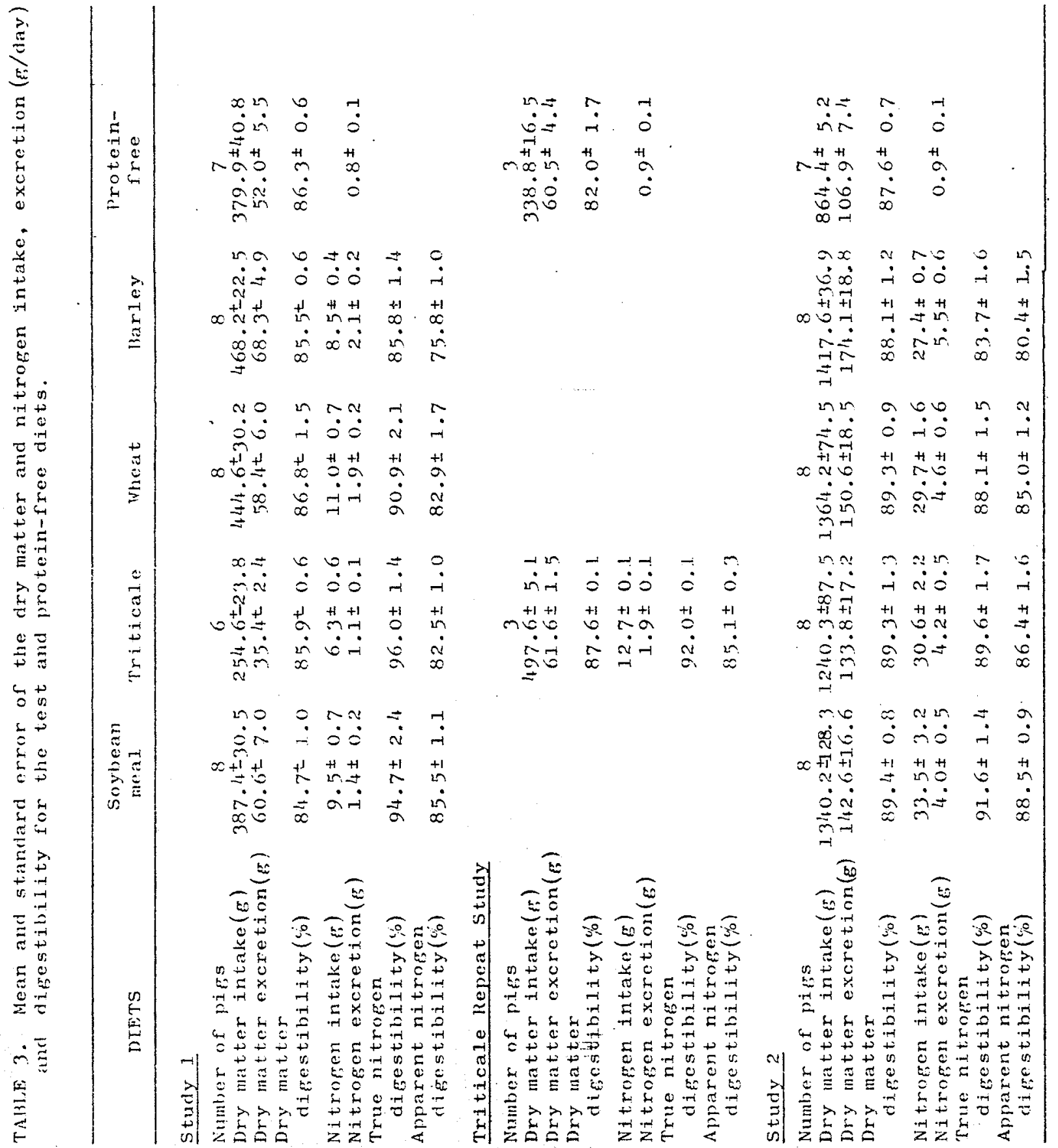




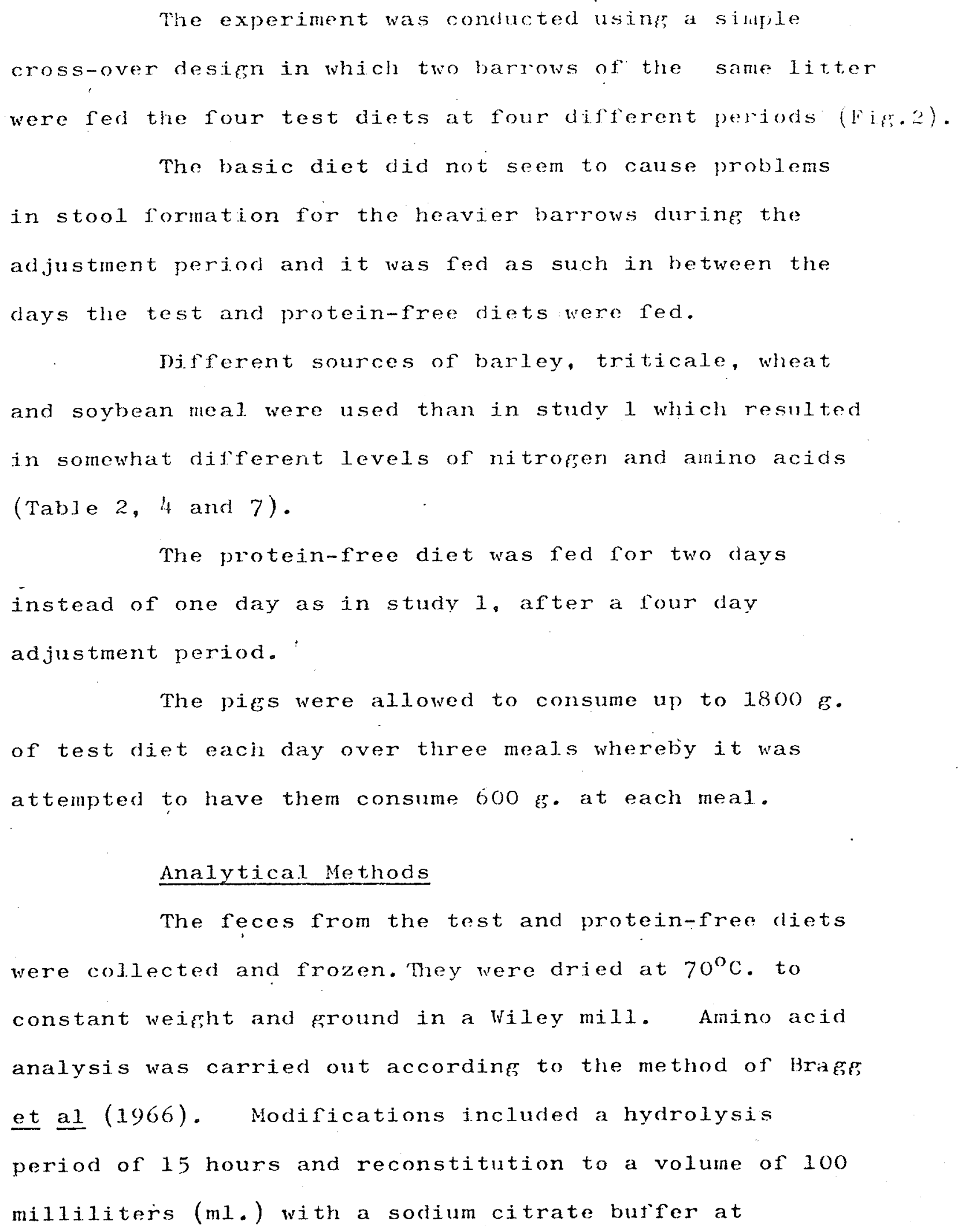


p.H. 2.2. One half ml. of each sample was analyzed on a model. 116 Beckman amino acid analyzer. Dietary and recal $N$ content were determined by the macro-kjeldahl method (Horowitz, 1965). Duplicate analyses were carried out for $N$ and amino acids on the diets while a single analysis was performed on fecal material. Statistical. methods used were analysis of variance, Duncan's multiple range test, determination of missing values and arcsin transformation according to Stee 1 and Torrie $(1960)$ 


\section{RESUL'TS}

The anino acid availabjlities from bas ley, wheat, triticale and soybean moal were deterninod. Tho availabilities of tryptophan and cystoine could not be determined since tryptophan is destroyed and cysteine is partially destroyed during acid hydrolysis.

The rixst study was carried out on Managra barrows that weifhed around Jo krr., while the second study was carried out on harrows that weighed around $30 \mathrm{~km}$. at the start of the experiment.

True anino acid availability from the test diets

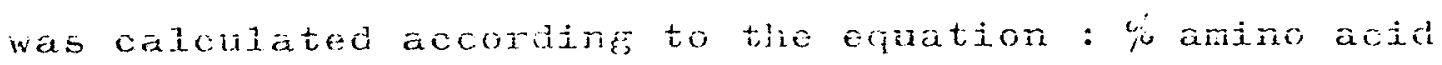
availability = [amino acid jutake-(fecal. arino acids metabolic recal amino acids)] x $100 /$ amino acia intake. Metabolic fecal anino acids were not considered in the calculation of apparent amino acid availability.

\section{Study 1}

1. Apparent and true avajlability between test diets Jata from both exporinents, which involved different pigs and wich were carried out at different times in the form of a Latin Square design, were combined in one statistical analysis. One fecal collection was missing trom each Latin Square due to the fact that a low dietary consumption of triticale made it impossible to separate the reces of it from the red coloined feces of 
the "modified basic diet". Determination of missing

values and their subsequent use in determining the $r$ values in the analysis of variance contribute a bias towards the mean square for treatment. However, it was not necessary to renove this bias in the computations for arriving at the real $F$ value since the $F$ value obtained usually exceeded the 5\% level of significance by a wide margin. Metabolic fecal amino acid excretion was very similar for each of the four pifs in the rirst experiment (Latin Square 1 ) of study $I$ as shown by the small standara errors (Appendix, Table 11). Therefore, in order to calculate the true amino acid availabilities, individual metabolic fecal ainino äcia excretions were taken into account for each of the four pigs. However, metabolic fecal amino acid excretion varied extensively between the pigs in the second experiment (Latin Square 2) of study 1 due to one of the pigs having consumed only about half the amount of protein-free diet $(180 \mathrm{g.})$ as compared to the other three pigs. Fecal separation problems were encountered for this particular pig as well. As a result, the average metabolic fecal amino acid excretion of the other three pigs was used in calculating the true amino acid availabilities of the test diets (Appendix, Table 11 ). 
One notices a low consumption of triticale

relative to that of the other test diets and a low ratio of $N$ from triticale feces and from the feces derived from the protein-free diet (Table 3). This obviously caused the high true availabilities for the amino acids from triticale (Table 4). There was also a problem in separating the triticale feces from the feces derived from the "modiried basic diet". For this reason, true and apparent anino acid availabilities from the triticale repeat experinent were entered in Table 4. Most attention will be paid to these triticale anino acid availability estinates during the presentation of the results and their discussion. The anino acid availability estimates of the triticale repeat experiment were from three pigs only instead of four. Data from one animal were ignored due to problems in fecal separation because of diarrhea.

\section{a) Apparent availability}

The availabilities of six of the ten essential amino acids from soybean meal were significantly higher $(\mathrm{P}<.05)$ than those from triticale, wheat and barley. Specifically these amino acids were arginine, isoleucine. leucine, lysine, threonine and valine (Table 4 ). Especially remarkable were the large differences in lysine availability between the four test diets. Lysine availability was $82.5,66.6,61.6$ and $57.6 \%$ for soybean meal, triticale (original study), wheat and barley 


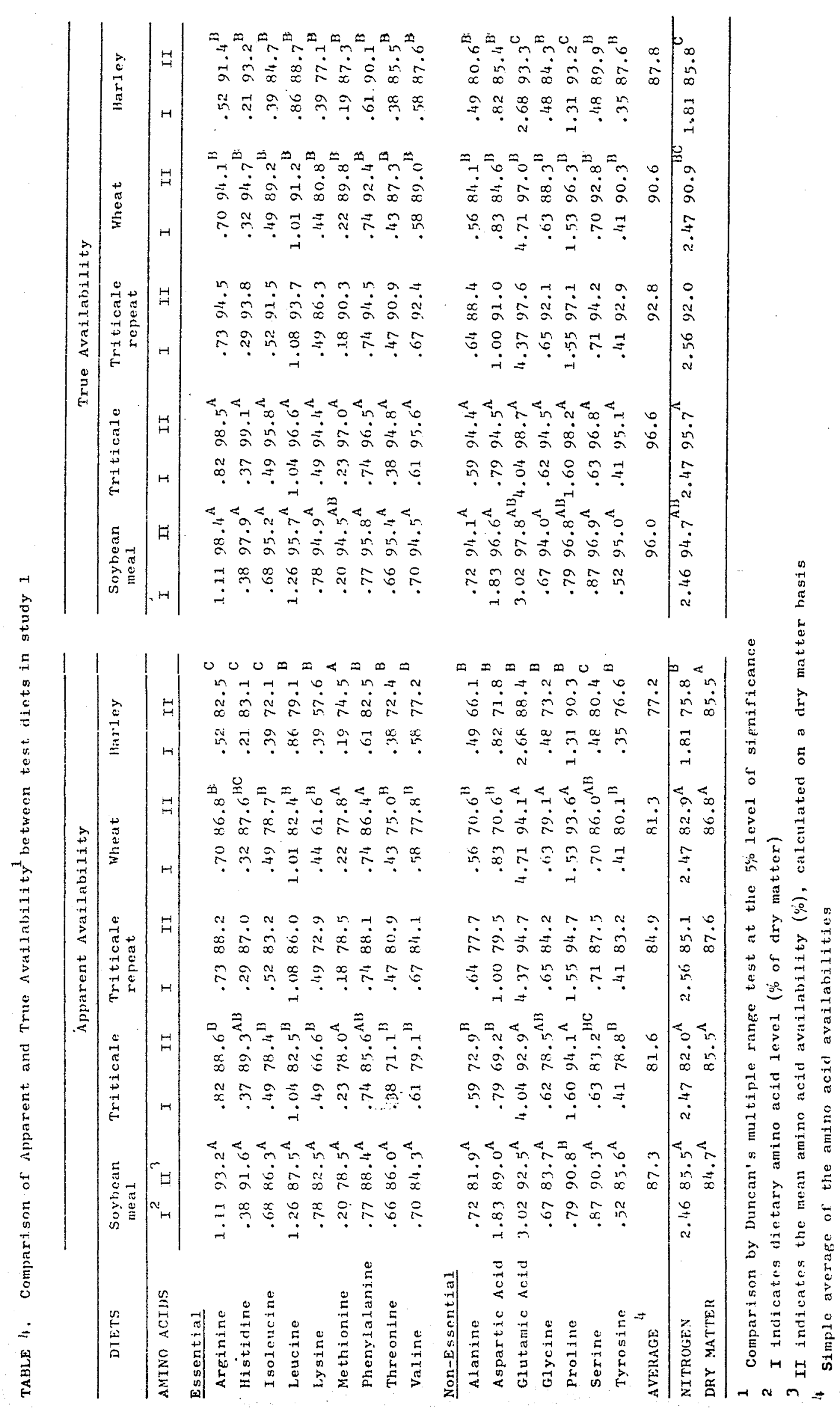


respectively. The availability of histidiute from soybean moal was himher than grom tritisale but not significantly. Neither was there a significant difference between the phenylalanine availabilitios from soybean moal, triticale (oriminal study) and wheat. Methionine availability remained essentially the same regardless of the type of diet red.

The relative relationships between the arparent amino acid availabijities of the cereal grains were comparable for study 1 and 2 only when the availabilitios of the orifinal triticale exporinent of study 1 were substituted by those of the triticale repeat experiment of stury $i$ (Tabie it anci $T$ ). Therojore, reference is nade to the amino acid availabilitios from the triticale repeat experiment for assessing; the differences betweon the essential amino acid availabjlities of the cereal grains in study 1. The availabilities of all the essential amino acids that were determined decreased from triticale to wheat to barley. The average amino acid availability decreased rrom 84.9 to. 81.3 to $77.2 \%$ for triticale, wheat and harley respectively (Table $t_{\text {) }}$. There were only small differences between the apparent $N$ dipestibilities and the average apparent amino acid availabilities for each diet tested. The $N$ 
digestibilities from soybean meal, triticale (original study) and wheat were significantly higher than the $\mathrm{N}$ digestibility from barley while there were no significant differences among the dry matter digestibilities of the test diets (Table 4 ).

The amino acid availabilities from the triticale repeat experiment were generally higher than those from the original triticale study, concomittantly with a higher $N$ and dry matter digestibility. (Table 4 ).

b) True availability

The difference in the percentage of true and apparent averagre amino acid availability for the triticale repeat study was 7.9 which corresponded well with the differences for the other test diets, while the difference obtained in the original study on triticale was $15 \%$ (Table 4). Overestimation of the true amino acid availabilities for the original triticale study were caused by the low intake of triticale relative to that of the protein-free diet (Table 4). Therefore, for comparison of the true amino acid availabilities between the test diets, reference will be made only to those of the triticale repeat experiment.

The true availabilities, like the apparent availabilities, of the amino acids from soybean meal were higher than those from the cereal grains (Table 4 ). 
The average true amino acid availability was 8.7, 7.9, 9.3 and $10.6 \%$ hisher than the average apparent availability from soybean meal, triticale, wheat and barley respectively. The increase was highest for those amino acids that had a low apparent availability and the lowest for those that had a hish apparent availability. For example, the true methionine availability in soybean meal was $16 \%$ higher than the apparent availability while the true arginine availability was only $5.3 \%$ higher.

The true $N$ digestibility decreased from soybean meal to triticale to wheat to barley as did the averare true amino acid availability. The average true amino acid availability was more or less the same as the $N$ digestibility for each specific test diet (Table 4 ). 2. Apparent and true availability within test diets. Combined data are shown in Table 5 and 6. Again, amino acid availability studies from the triticale repeat experiment have been included in the tables. Statistical analyses on data of the original triticale sturly have been carried out on only six fecal collections from triticale due to fecal separation problems in two instances.

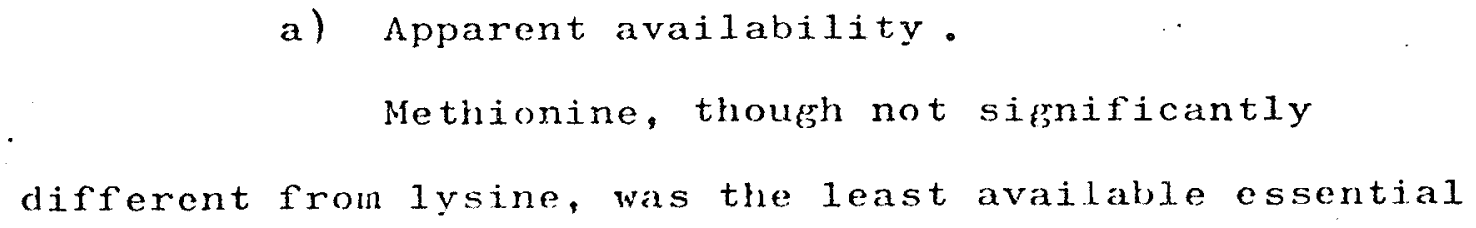




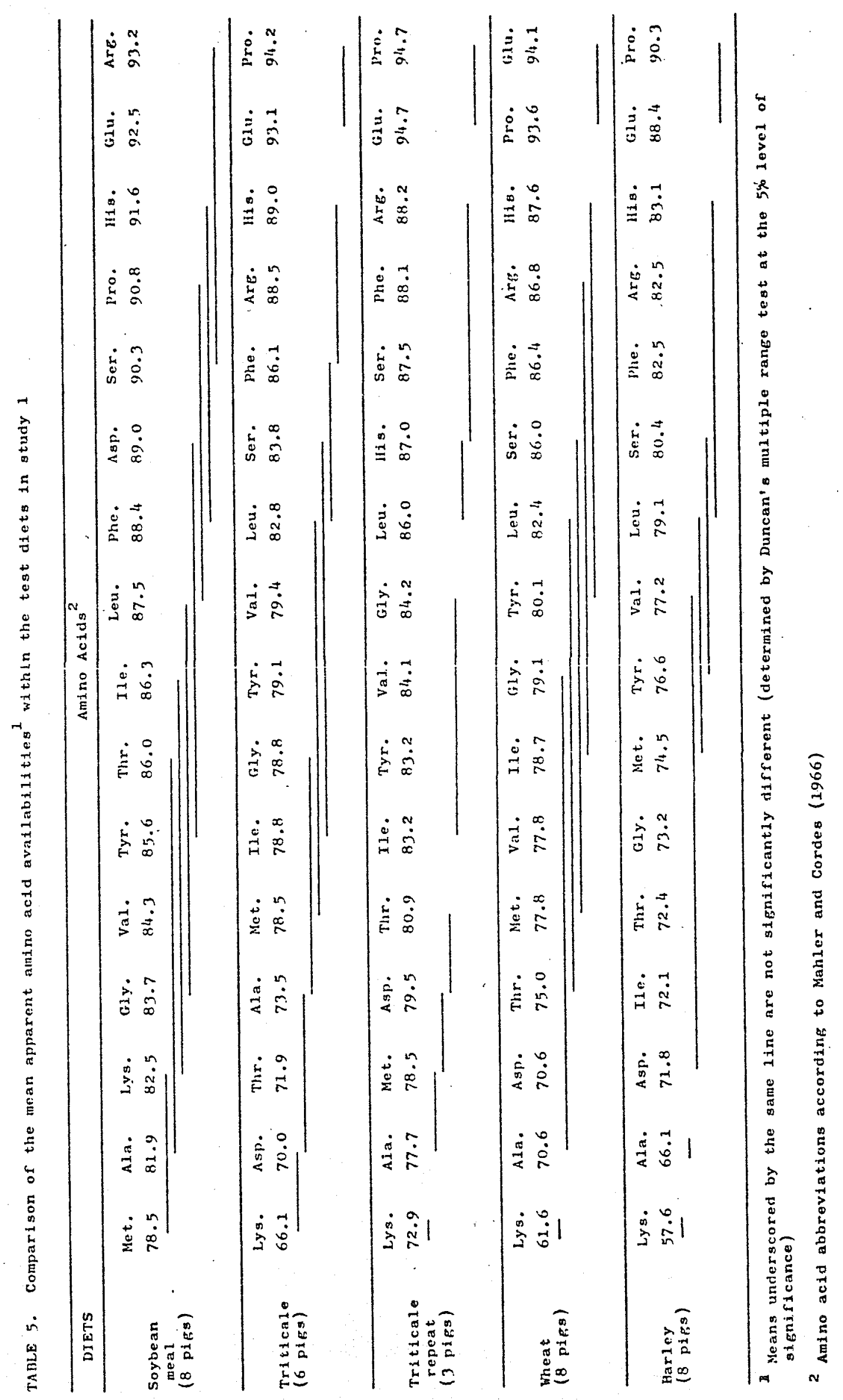




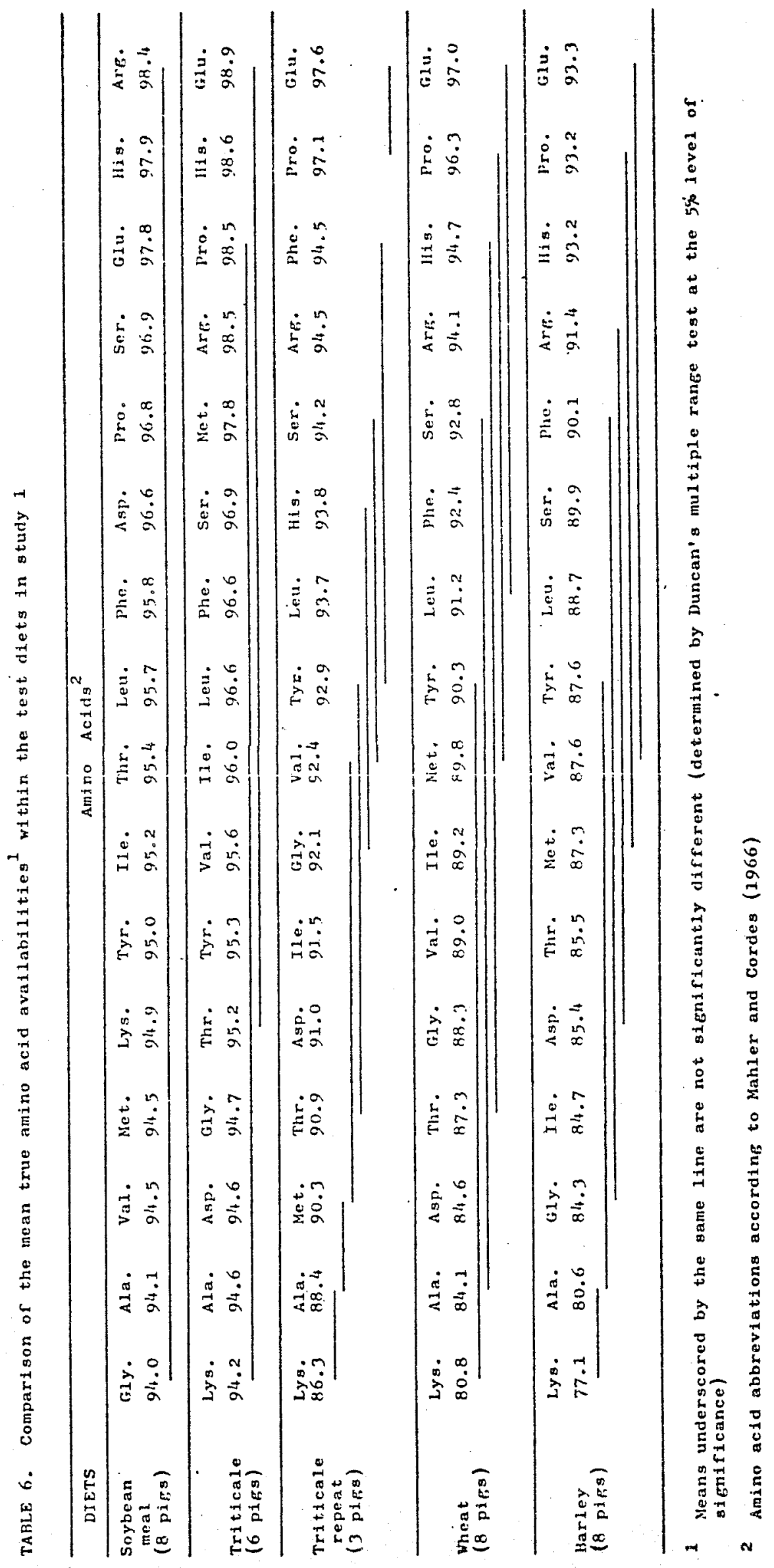


amino acid in soybean meal. Arginine and histidine were the most available essential anino acids in soybean rabl, which was also the case for the cereal frains (Table 5). For the cereal grains, lysine was the least available essential amino acid $(\mathrm{P}<.05)$ with availabilities of $66.1,61.6$ and $57.6 \%$ for triticale, wheat and barley respectively. Lysine was also least available in the triticale repeat experiment, namely $72.9 \%$

Generally, the availabilities of the essential amino acids of the cereal grains can be classified in four groups from low to high availability: 1) Lysjne, which is least available, 2) Isoleucine, methionine, threonine and valine which are second least available, 3) Lencine; 4) Arginine, histidine and phenylalanine which are the most available essential amino acids.

For the non-essential anino acids, alanine and glycine were least available in soybean meal. Alanine and aspartic acid were least available in wheat, triticale and barley. Glutamic acid and proline were the most available of the non-essential amino acids of the four test diets.

The sequence of amino acid availability obtained from the triticale repeat experiment did not compare too unfavourably to that obtained from the original triticale experiment in that lysine was least available and arginine and phenylalanine were the most available of the essential 
amino acicls in both experiments.

b) True availability

The margin between the percentages in

availability of the amino acids was much smaller for true than that for apparent availability as was illustrated for soybean meal. where the difference between the least and most available anino acid was only $4.8 \%$ (Table 6).

The sequence of true availability for the essential amino acids from wheat and barley was identical to that for apparent availability and was almost identical regardingr the non-essential anino acids. This was also true for the triticale repeat experiment.

\section{$\underline{\text { Study } 2}$}

1. Apparent and true availability between test diets The comparisons of true and apparent amino acid availabilities between the test diets for the heavier pirs are shown in Table 7 .

One animal did not consume the protein-free diet at a11. The metabolic fecal amino acid excretion varied extensively for the other seven pigs as shown by the large standard errors (Appendix, Table 12). Therefore it was decided to use the average metabolic fecal amino acid excretion for calculating the true amino acid availabilities. 


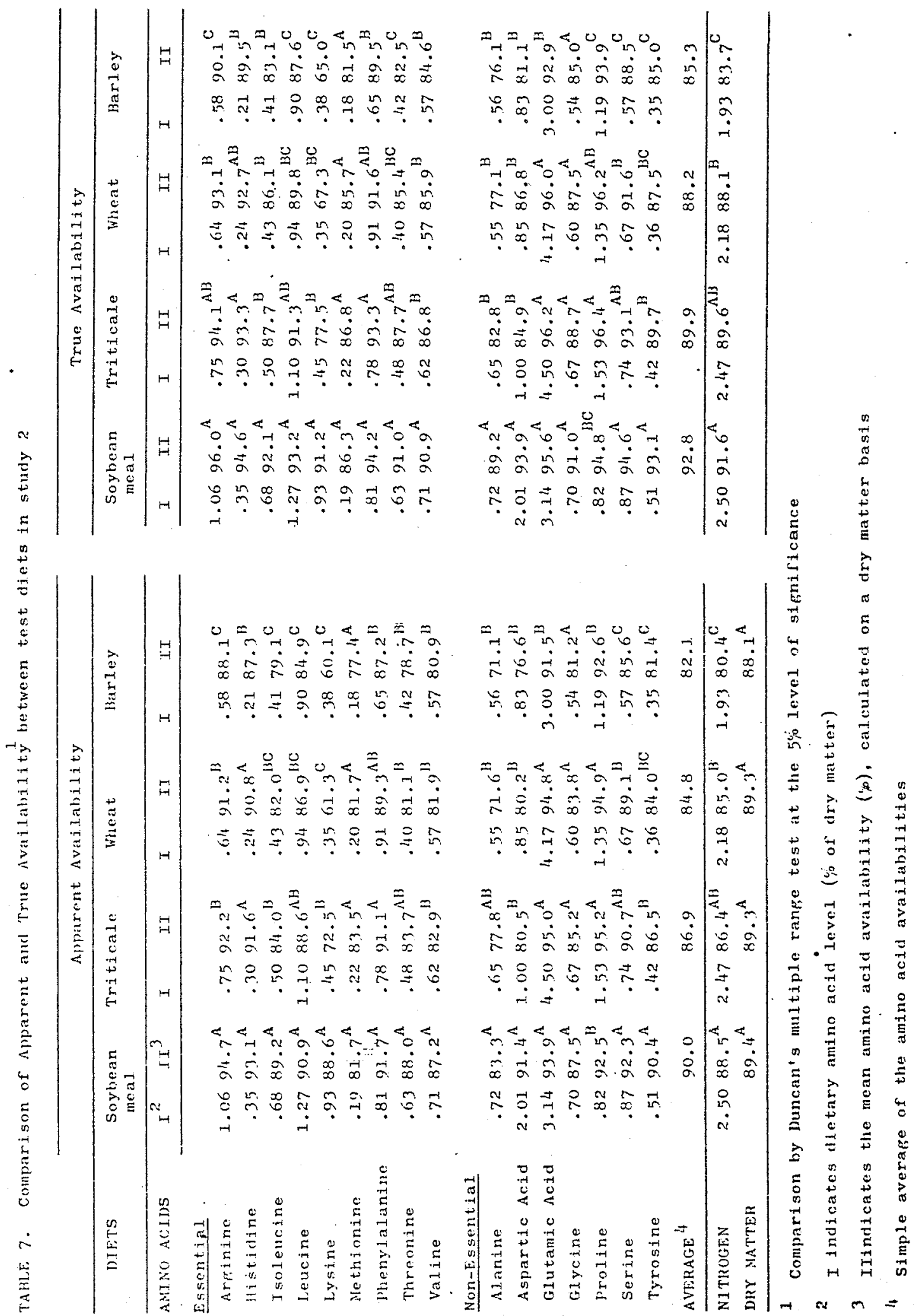


a) Apparent availability

But for methionine, the availabilities of

all essential arino acids studied in soybean meal were higher than those from the cereal grains. However, this was only true for arginine, isoleucine, lysine and valine on a significant $(\mathrm{P}<0.05)$ basis. There were no differences in availability for histidine and phenylalanine between soybean meal, triticale and wheat. Neither were there significant differences $(p<0.05)$ for leucine and threonine between soybean meal and triticale. As in study 1 , methionine availability did not seem to depend on the diets used (Table 7 ).

Numernus differences in amino acid availabilitios between the cereal grains were noted. From all the essential amino acids studied, only the availability of lysine was significantly higher $(P<0.05)$ in triticale than in wheat. But for threonine and valine, the availabilities of the essential amino acids in triticale were significantly higher ( $P<0.05$ ) than those from barley. The availabilities of arginine and histidine in wheat were significantly higher $(1<0.05)$ than those rrom barley.

The availabilities of the non-essential amino acids in soybean neal were higher than those from the cereal grains, excepting glutamic acid and proline whose availabilities were highest in triticale and wheat. 
Nitrogen difestibility followed the average amino acid availability very closely for each of the test diets as in study 1. There were no significant differences in dry matter digrestibilities between the test diets $($ Tab1e 7$)$.

Although the individual availability estimates of the amino acids in this study differed to some extent from those in study 1 in each of the test diets, the rolative relationship of the amino acjds between the test diets was much the same (Table 4 and 7 ).

b) True availability

The average true amino acid availability was $2.8,3.0,3.4$ and $3.2^{6}$. nigher than the average apparent amino acid availability for soybean meal, triticale, wheat and barley respectively and they closely followed the true $\mathrm{N}$ digestibility (as in study 1 ), which was about $3 \%$ higher than the apparent $N$ digestibility (Table 7 ).

The differences between the average apparent and true amino acid availabilities were much smaller in this study than in study 1. Relatively, there was a higher ratio of $N$ excreted in the feces of the test diets to that in the feces of the protein-free diet in this study (Table 3 ). Generally, sinilar significant trends were noted for the true and apparent anino acid availabilities from the four test diets. 
2. Apparent and true availability within test diets The comparisons of true and apparent anino acid availability within the test diets are shown in table 8 and 9.

a) Apparent availability

Lysine was significantly $(l<0.05)$ the least available essential amino acid in triticale, wheat and barley. Methionine was the least available essential amino acid in soybean meal (Table 8).

A remarkable similarity in the sequence for amino acid availability was noted for the cereal grains. The sequence was the same except for isoleucine, methionine, threorine and valine but regarding lineir avaidabilities these amino acids were not significantly different from each other with each cereal grain.

The availabilities of the essential amino acids in the cereal frains studied can be classified in the same groups as described for study 1 .

Alanine was the least available non-essential amino acid, glutamic acid and proline were the most available in all diets tested. Aspartic acid was the second least available non-essential anino acid in the cereal grains. On the contrary, aspartic acid had a relatively high availability in soybean meal. 


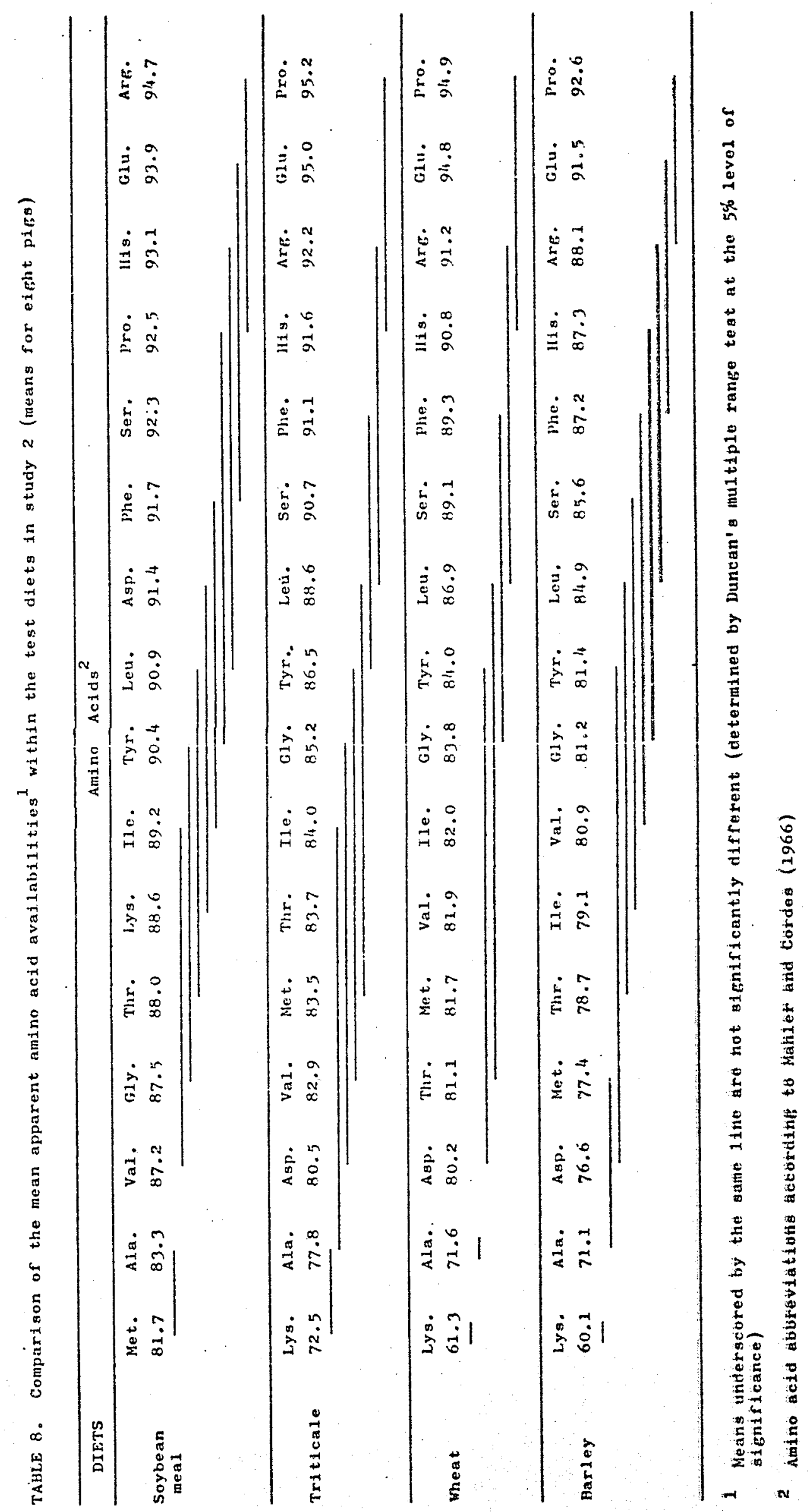




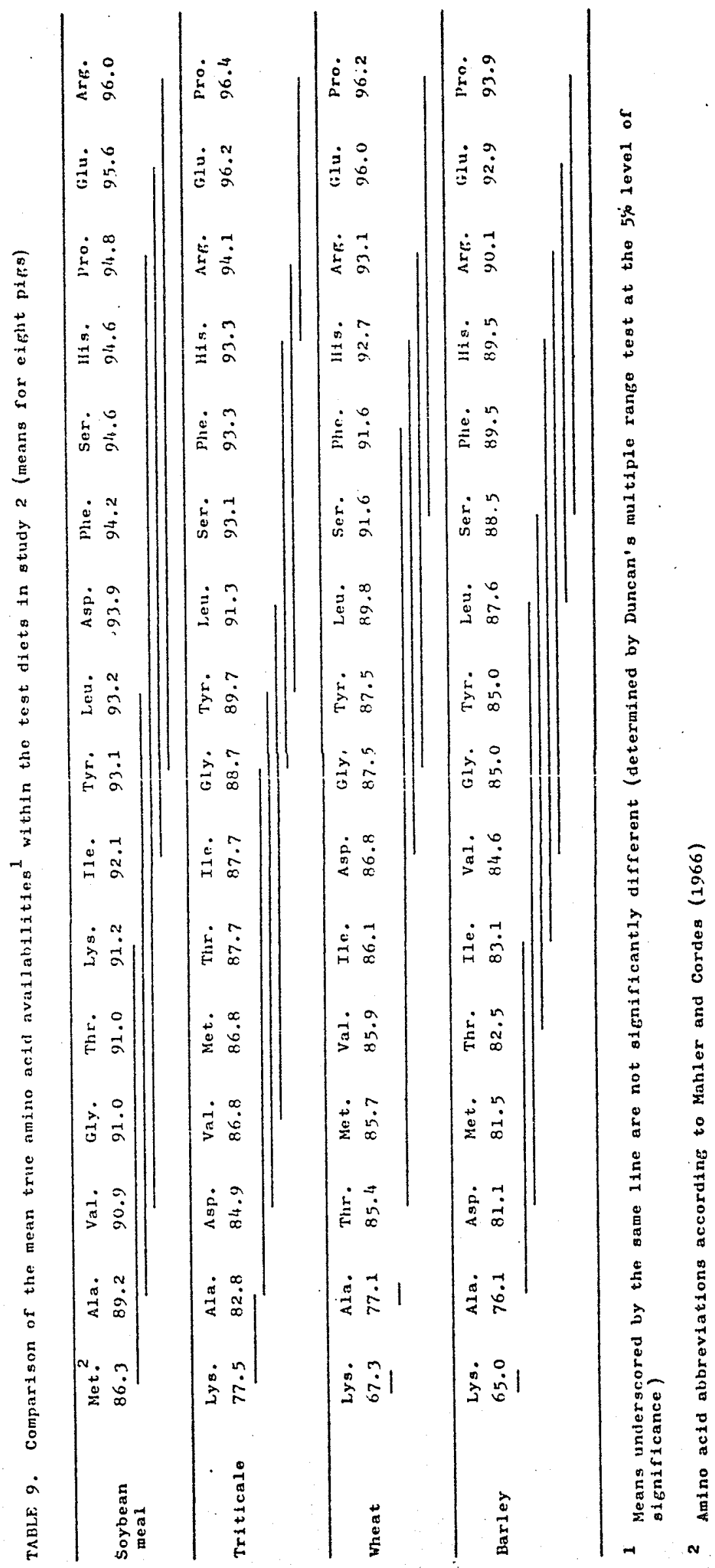


b) True availability

The sequence for the amino acids in true availability was nearly identical to that for apparent availability for all diets studied (Table 9). 


\section{DISCUSSION}

Comparisons between the dietary amino acid

availabilities when the drv matter intake or excrotion of the protein-free diet is made erual to that of each tast diet

As was pointed out in the literature review, it is important to have the same amount of indigretible material in the protein-free and test diet in order to determine the true $N$ digestibility and the true anino acid availabilities or a protein (or protein source).

Besides, the test animals should consume the same amount of both diets.

Cellulose was included at a level of 13.2 and 20\% in the soybean meal ard protein-free diet respectively in order to obtain about equal dry matter digestibilities for the test and protein-free diets (Table 2). Although the dry matter digestibilities were nearly sinilar, the amount of dry ratter excreted differed widely due to the difference in dietary consumption of the test and protein-free diets. (Table 3$)$. Therefore, calculations for true anino acid availability estimates were carried out in which the amount of each metaholic fecal anino acid, as determined by feeding the protein-free diet, was corrected for cqual consumption and dry matter excretion of the protein-free diet and each test diet. The correction factors are given in Table 10, while the corrected true amino acid 


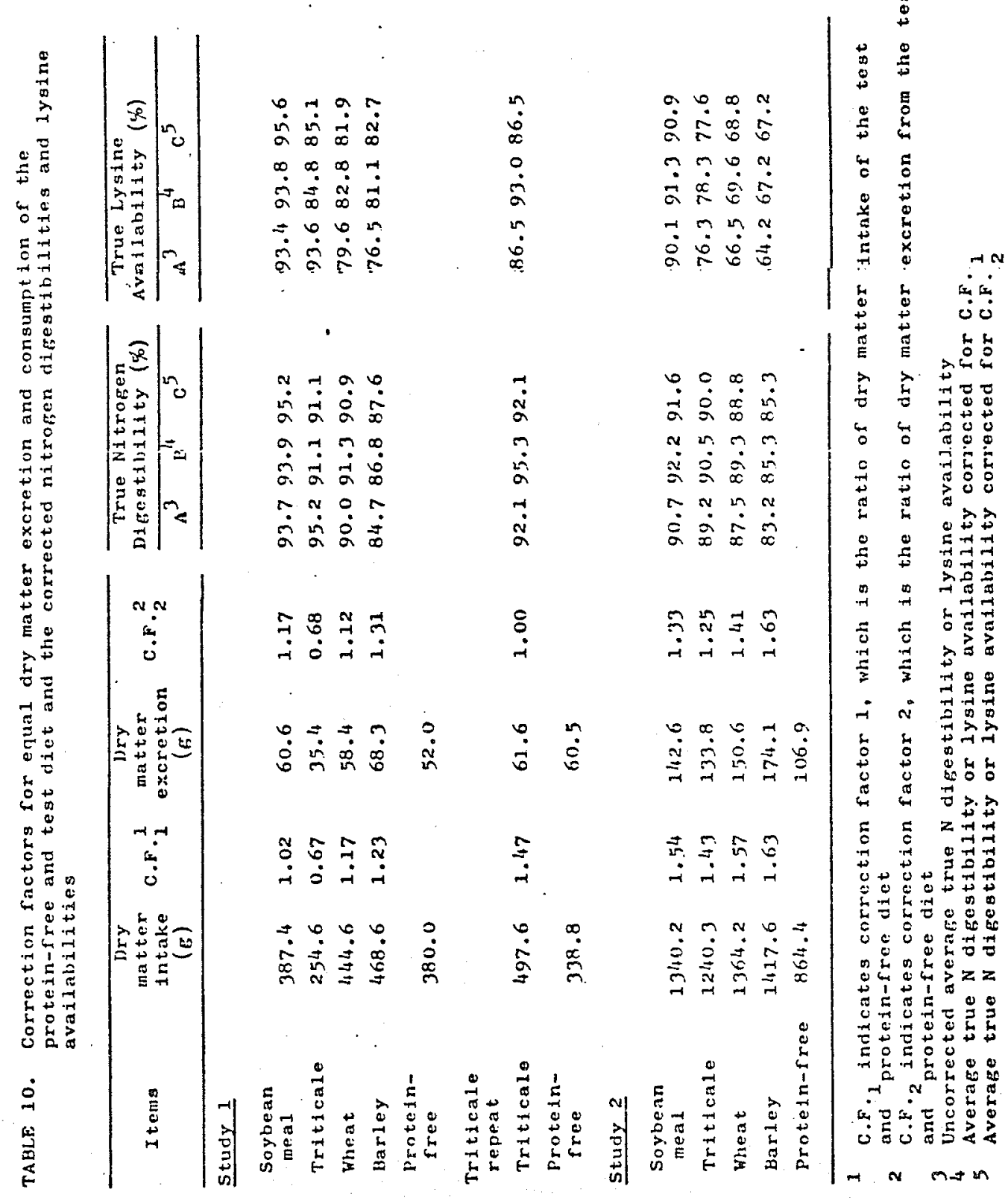




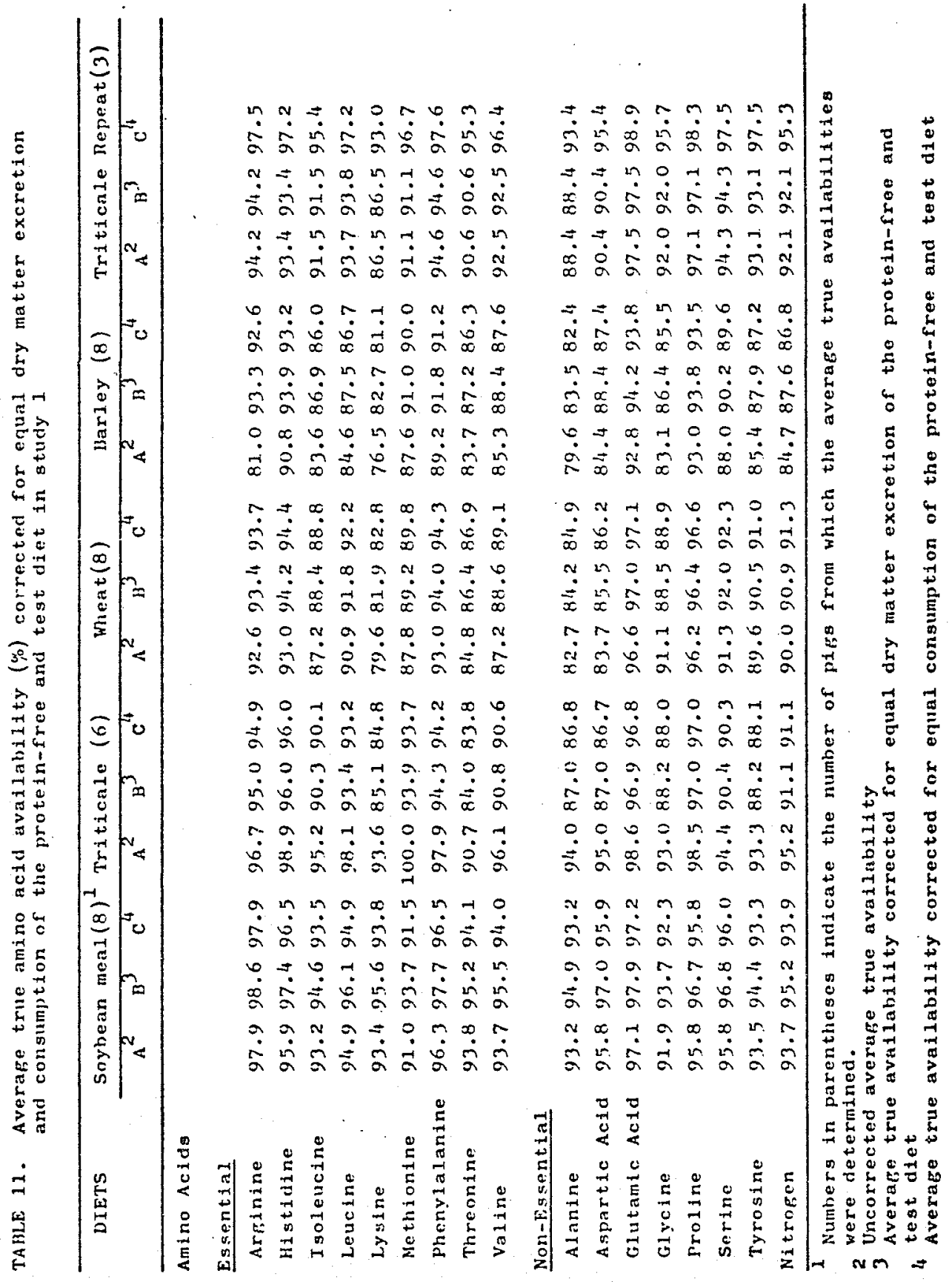




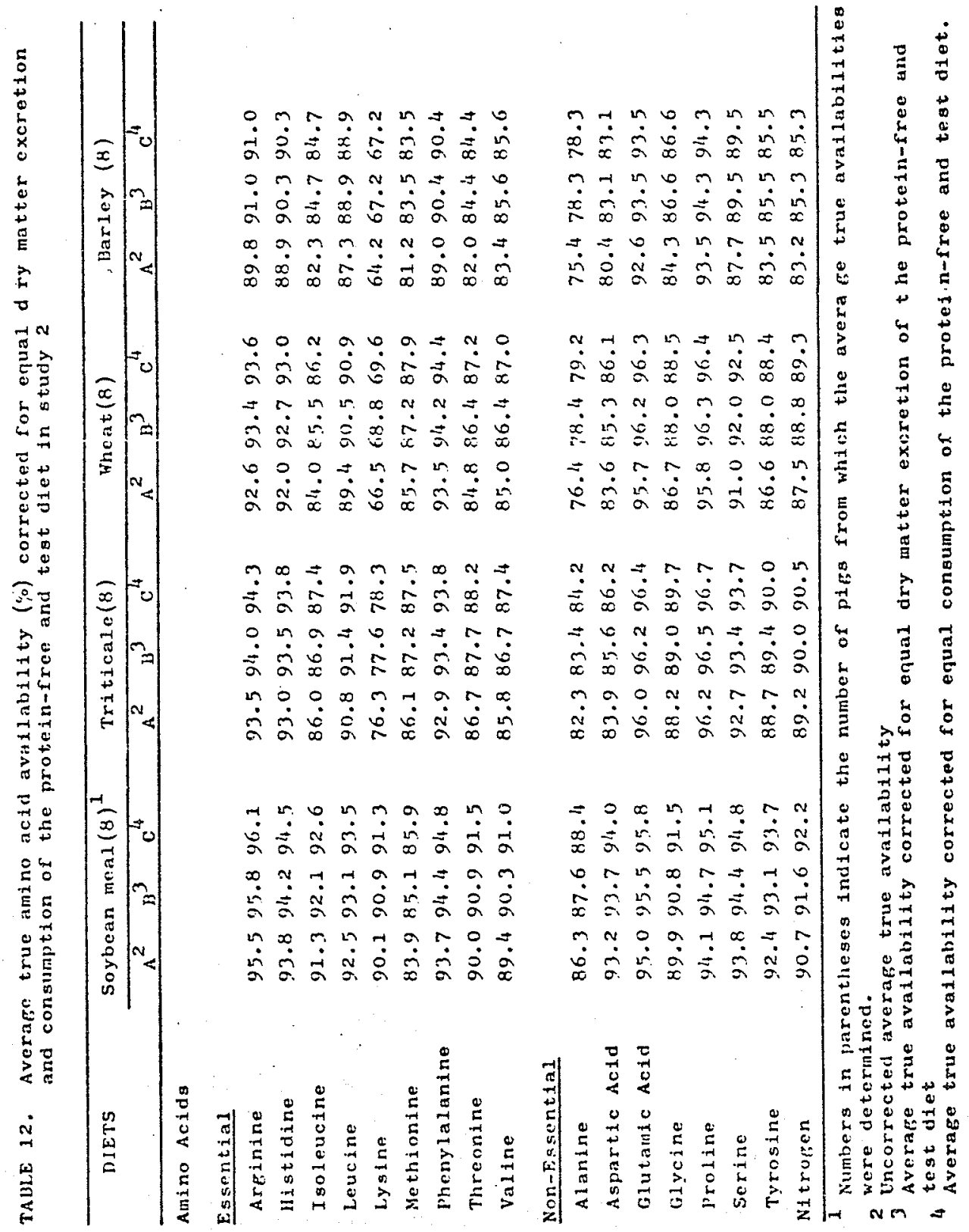


availabilities are given in Table 11 for study 1 and in Table 12 for study 2. Average dietary consumption and fecal excretion of amino acids for each of the test diets and the average metabolic recal anino acid excretion were used in order to minimize computations (Appendix, Tables 11,12 and 13 !

Corrections of metabolic fecal amino acid levels by factors larer than 1 increased true amino acjd availability estimates, those smaller than 1 decreased these estimates. The least available anino acids decreased or increased the most. Hoth types of corrections resulted in noarly similar true $N$ difrestibility estimates except for the triticale repeat experiment where they differed by $3.2 y^{\circ}$ (Table 10). Presmably too nuch indigestible fecal dry matter was collected in this case from the protein-free diet (page 69). The dry matter digestibility of the protein-free diet from the triticale repeat experiment was about 5 lower than those obtained from study 1 and 2 (Table 3) and correction for equal intake of the protein-free diet and triticale increased the metabolic fecal $N$ excretion once more so that it resulted in a true $N$ digrestibility estimate that was even higher than those fror soybean meal (Table 10).

Therefore, the true $N$ digestibility and true amino acid availability estimates obtained by correcting for equal dry mater excretion will be cited from the triticale 
repeat experiment when compared to those obtained from triticale in study 2 .

The corrected true $N$ alirestibility estimates ${ }^{I}$

between studies 1 and 2 for the same dicts were closer than the original estimates, i.e. 1.7, 1.6, 2.0 and 1.5\% for soybean meal, triticale, whoat and barley respectively (Tables 10, 11 and 12). However, the corrections faijod to make the true availabjlity estimates of some anino acids, in particular those of lysine from the cereal Erains, more comparable (Tables 10,11 and 12).

The correcter metabolic recal. $N$ and amino acid levels are fiven in Table 13 for each of the diets. About so, nore $N$ was excroted by the pins from studv 2 . which were about $20 \mathrm{k}$ r heavier than the pigs from study 1 during the course of the experiments. Whiting and Bezeau (1957) reported that for each unit increase in body weight (kg) to the 0.3 power, there was a $0.12 \mathrm{~g}$ decrease in metabolic fecal iv excretion per 100 gr dry matter intake in diets containing between 5 and $18 \%$ protein (by extrapolation of the regression line of fecal $N$ on $N$ intake). However, hy dircet measurenents using; low protein diets $(0.3 \% \mathrm{~N})$, they found a 0.06 g decrease in metabolic recal $N$ excretion per loo or dry matter intake.

1 Compared on a hasis of equal dry matter consumption of the protein-free and test diet in case of soybean meal, wheat and harley. Triticale in study 1 frow the triticale repeat experiment (corrected for equal ary mattor excretion) and triticale from study 2 (corrected for equal intake) were compared. 
TABLE 13. Comparison of the corrected metabolic fecal amino acid excretion (g) from the lighter (study 1) and heavier pigs (study 2)

\begin{tabular}{|c|c|c|c|c|c|c|c|c|}
\hline \multirow{2}{*}{$\begin{array}{l}\text { DIETS } \\
\text { EXPIRIMENT }\end{array}$} & \multicolumn{2}{|c|}{$\begin{array}{c}\text { Soybean } \\
\text { meal }\end{array}$} & \multicolumn{2}{|c|}{ Triticale } & \multicolumn{2}{|c|}{ Wheat } & \multicolumn{2}{|c|}{ Barley } \\
\hline & $1(7)^{2}$ & $2(7)$ & $1(3)$ & $2(7)$ & $1(7)$ & $2(7)$ & $1(7)$ & $2(7)$ \\
\hline \multicolumn{9}{|l|}{ Amino Acids 3} \\
\hline \multicolumn{9}{|l|}{ Essential } \\
\hline Arginine & 0.21 & 0.25 & 0.23 & 0.23 & 0.24 & 0.25 & 0.25 & 0.26 \\
\hline Histidine & 0.09 & 0.09 & 0.10 & 0.09 & 0.10 & 0.09 & 0.10 & 0.10 \\
\hline Isoleucine & 0.21 & 0.34 & 0.22 & 0.31 & 0.24 & 0.35 & 0.25 & 0.36 \\
\hline Leucine & 0.38 & 0.52 & 0.41 & 0.49 & 0.44 & 0.53 & 0.46 & 0.55 \\
\hline Lysine & 0.36 & 0.40 & 0.33 & 0.37 & 0.41 & 0.41 & 0.44 & 0.42 \\
\hline Methionine & 0.11 & 0.15 & 0.11 & 0.14 & 0.13 & 0.16 & 0.13 & 0.16 \\
\hline Phenylalanine & 0.23 & 0.32 & 0.24 & 0.30 & 0.26 & 0.33 & 0.28 & 0.34 \\
\hline Threonine & 0.21 & 0.34 & 0.23 & 0.31 & 0.24 & 0.35 & 0.25 & 0.36 \\
\hline Valine & 0.28 & 0.43 & 0.28 & 0.40 & 0.32 & 0.44 & 0.34 & 0.46 \\
\hline Subtotal & 2.08 & 2.84 & 2.15 & 2.64 & 2.38 & 2.91 & 2.50 & 3.01 \\
\hline
\end{tabular}

Non-Essential

\begin{tabular}{lllllllll} 
Alanine & 0.32 & 0.57 & 0.34 & 0.53 & 0.37 & 0.58 & 0.39 & 0.60 \\
Aspartic Acid & 0.51 & 0.77 & 0.54 & 0.71 & 0.58 & 0.79 & 0.61 & 0.82 \\
Glutamic Acid & 0.59 & 0.94 & 0.62 & 0.87 & 0.68 & 0.96 & 0.71 & 0.99 \\
Glycine & 0.25 & 0.42 & 0.25 & 0.39 & 0.28 & 0.42 & 0.30 & 0.44 \\
Proline & 0.18 & 0.32 & 0.19 & 0.30 & 0.21 & 0.33 & 0.22 & 0.34 \\
Serine & 0.18 & 0.34 & 0.24 & 0.31 & 0.21 & 0.35 & 0.22 & 0.36 \\
Tyrosine & 0.15 & 0.25 & 0.20 & 0.23 & 0.17 & 0.25 & 0.18 & 0.26 \\
$\quad$ Subtotal & 2.18 & 3.61 & 2.38 & 3.34 & 2.50 & 3.68 & 2.63 & 3.81 \\
Total Anino & & & & 0.83 & & & & \\
$\quad$ Acids & 4.26 & 6.45 & 4.53 & 5.98 & 4.88 & 6.59 & 5.13 & 6.82 \\
Nitrogen & 0.82 & 1.39 & 0.91 & 1.28 & 0.94 & 1.41 & 0.98 & 1.47 \\
\hline
\end{tabular}

Comparison of metabolic fecal amino acid excretion from the triticale repeat experiment in study 1 with that of study 2

2

Numbers in parentheses indicate the number of pigs from which the average metabolic fecal amino acid excretion was determined.

Amino acid excretion expressed as crams per day 
The lighter pirs from study 1 excreted 0.211 g of metabolic feeal $N$ per $100 \mathrm{~g}$ dry matter intake as compared to $0.104 \%$ for the heavier pigs from study 2 (Table 3). A change in weight from 10 to $35 \mathrm{~kg}$ constitutes one unit increase in body weight to the 0.3 power, which corresponds approximately to the weight difference between the pigs from study 1 and 2. Thus, the difference obtained in metabolic fecal $N$ excretion per $100 g$ dry matter intatie between the pigs from study 1 and 2 compared well with the one obtained by Whiting and Bezeau (1957) by extrapolation but was higher than the one that they obtained directly by feeding a low protein diet.

The corrected metabolic fecal lysine excretion did not increase in the sane proportion as total $N$ from the lighter to the heavier pigs (Table 13). This may explain to a certain extent the lower corrected true lysine availabilities, in particular those of wheat and harley, of the test diets in study 2. The corrected true lysine availabilities vere 82.8 and $81.1 \%$ in study 1 and 69.6 and $67.2 \%$ in study 2 for wheat and harley respectively (Table 10 and 12). Assuming that lysine would increase proportionally to total $N$ from the younger to the older barrows, the recorrected metabolic fecal lysine excretion would be $0.61 \frac{1}{1}$ from wheat. The resulting recorrected

$\overline{1.41 / 0.94 \times 0.41}=0.61($ Table 13) 
true lysine avajlability from wheat would then be $73.0^{6} 0^{1}$ which differs now by only $9.8 \%$ (instead of $13.2 \%$ ) from that of study 1 (Tabie 10 and 13). Several reasons may be postulated as to why the metabolic fecal lysine excretion did not increase in the same proportion as total $N$ from the younger to the older pigs. First of all, the protein-free diet was fed for 2 days in study 2 as compared to 1 day in study 1. The pigs in study 2 might have adapted to the feeding of the protein-free diet by the second day by losing less retabolic fecal Iysine. This adaptation (if it occurred) seemed to be true for the essential amino acias as a whole, because the increase in total $N$ excrotion was mainly dus to increased losses of the non-essential amino acids (Table 13). Secondly, the intestinal flora change with age as was shown by Michel (1961). This migrht have been another reason for the difference in metabolic fecal amino acid composition between that of study 1 and study 2 (Table 14 and 15$)$.

Whiting and Hezeau (1957) reported that, as the pigs increased in weipht from 15 to $50 \mathrm{~kg}$, the apparent digestibility of a protein increased. This was duc to

1 The average fecal lysine excretion from wheat was $1.90 \mathrm{~g}$ (ippendix, Table 12); the recorrected metabolic fecal lysine excretion was $0.61 \mathrm{~g}$ (Table 13); the average dietary lysine consumption from wheat was $4.77 \mathrm{~g}$ (Table 2 and 7 ). 
the fact that the netabolic fecal N excretion per loo r dry matter consumed, decreased in proportion to the 0.3 power of body weight. The apparent $N$ digestibility was $3.0,1.3^{1}, 2.1$ and $4.6^{\circ}$ hisher in study 2 than in study 1 for soybean meal, triticale, wheat and barley respectively (Table 4 and 7 ) and confirms the observations by Whiting; and liezeau. However, as was shown by Whiting and Bezeau (1957), the true protein digestibility (at dietary levels of 5 to 22,0 from wheat, skimmilk powder and fishmeal) did not changre significantly as the pirs increased in weight from is to $60 \mathrm{~kg}$. The true $N$ digestibilities, corrected for equal intake of the test and protein-free diet, were slightly higher in study 1 than in study 2. For example, the true $N$ digestibility of wheat was $2 \%$ higher in study 1 (Table 10). The recorrected true lysine avajlability from wheat in study 2 would be $76 \%{ }^{2}$, if the true $N$ digestibility of wheat in study 2 is made equal to that

1

Between triticale from the triticale repeat experinent in study 1 and triticale in study 2 .

The average fecal lysine excretion from wheat was $1.90 \mathrm{~g}$ (Appendix, Table 12); the corrected metabolic fecal lysine excretion was $0.41 \mathrm{kr}$ (Table 13); the recorrected $N$ excretion would be $100-91.3=8.7$ m instead of $100-89 \cdot 3=10.7$ g per 100 gr of dietary $N$ in study 2 (Table 10) and the recorrected dietary lysine loss would then be $\frac{8.7}{10.7}(1.90-0.41)=1.15 \mathrm{~g} ;$ the average dietary lysine intake from wheat was $4.77 \mathrm{~g}$ (Table 2 and 7). 
of wheat in study 1 , which differs now by only $6.8 \%$ from the corrected true lysine availability of wheat in study 1 (Table 10$)$. Thus, the relatively large differences in true lysine availabilities from the cereal frains between study 1 and 2 may be attributed partly to the relatively smaller differences in true $\mathrm{N}$ digestibilities between both studies for each of the cereal grains. Corrections on a basis of equivalent $N$ digestibility would make the true availabilities of the least available anino acids, since these increase or decrease the most, more coruparable between both studies for the cereal grains.

$$
\text { Significant differcnces }(T<0.05) \text { vere tound for }
$$
dry matter digestibilities between the test periods in study 2. Consequently, significant differences $(P<0.05)$ were found for $N$ digestibility and anino acid. availabilities (Appendix, Tables 3,4 and 14 ). However, no significant differences $(\rho<0.05)$ were found between the test diets regarding their dry matter digestibilities and they can thus not be held responsible for the difrerences in $N$ digestibility and amino acid availabilities that were found hetween the test diets. The dry matter digestibility decreased from $92.1 \%$ in test period I to $86.5 \%$ in test period IV. Inclusion of ferric oxide in the basic diet permits easier identification and collection of feces resulting from the test and protein-free diets. However, a gradual colour 
change is usually observed from red to that of the colour of the feces from the test diets. Therefore, N digestibility and amino acid availabilities from a test diet will also be dependent on the colour appraisal by the individual collecting the feces. The author has to admit to have erred by being inconsistent in colour appraisal over the 4 test periods in separating the red coloured feces of the basic diet from that of the feces of the test diets in study 2. The individual ${ }^{1}$, who collected and separated feces in study 1, did not comit this error. The so-called "colour appraisal ractor" is an error which is inherent in this type of experimental work. This error might be minimized by feeding the test diets for longer periods instead of only 1 day. It was not possibie to feed the test diets for more than 1 day in study 2. The pigs, which weighed around $30 \mathrm{~kg}$ at the start of the experiment, would have been too big for the cages by the end of the experiment. It would have been possible to feed the test diets for 2 days in the first study which involved pigs that weighed around $10 \mathrm{~kg}$ at the start of the experiment.

In future availability research, it would be advisable to use a different basic diet, for example, a basic diet containing casein as the protein source. The

1 Dr P.M. Giovannetti 
amino acids from casein aro highly available as was shown by Carlson and Bayley (1970). Contamination of . unavailable amino acids in the feces from the test diets by the unavailable amino acias in the feces of the basic diet would then be minimized.

Comparisons between the dietary and fecal amino acid levels when expressed as 5 amino acid/16 g njtrofen and its implications

The fecal levels $(\xi / 16 \mathrm{~g} N)$ of arginine, histidine, phenylalanine, glutamic acid, proline and serine, corrocted or not corrected for metabolic fecal contributions, were lower than the dietary levels in both study 1 and study 2 (Table 14 and 15). The availabilities of these amino acids were higher than the total $N$ digestibility and were usually the most available amino acids of the four test diets (Table 4 and 7). These observations may indicate: 1) the indigestible $\mathrm{N}$ residues contain low levels of these amino acids relative to the digested and absorbed $N$ fractions from these plant protein sources and/or, 2) these amino acids are preferentially degraded by the microflora of the alimentary tract. Carlson and Bayley (1970) fed piglets a $14 \%$ protein diet using casein, an animal protein source. They found lower fecal than dietary levels $(g / 16 ; \mathrm{N})$ of phenylalanine, glutamic acid, proline and serine. The levels of arginine and histidine were not determined in their studies. It would seem that the 


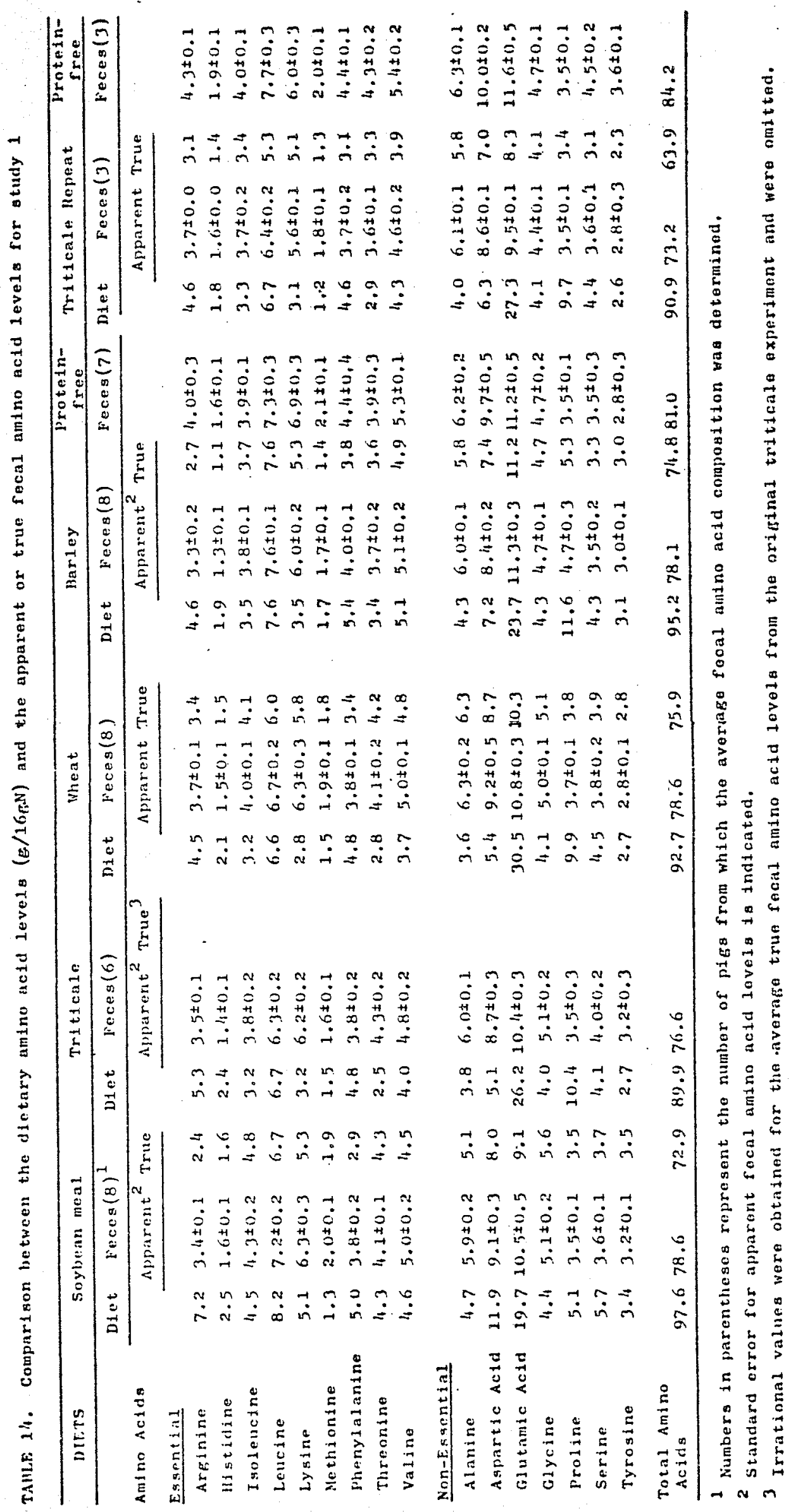




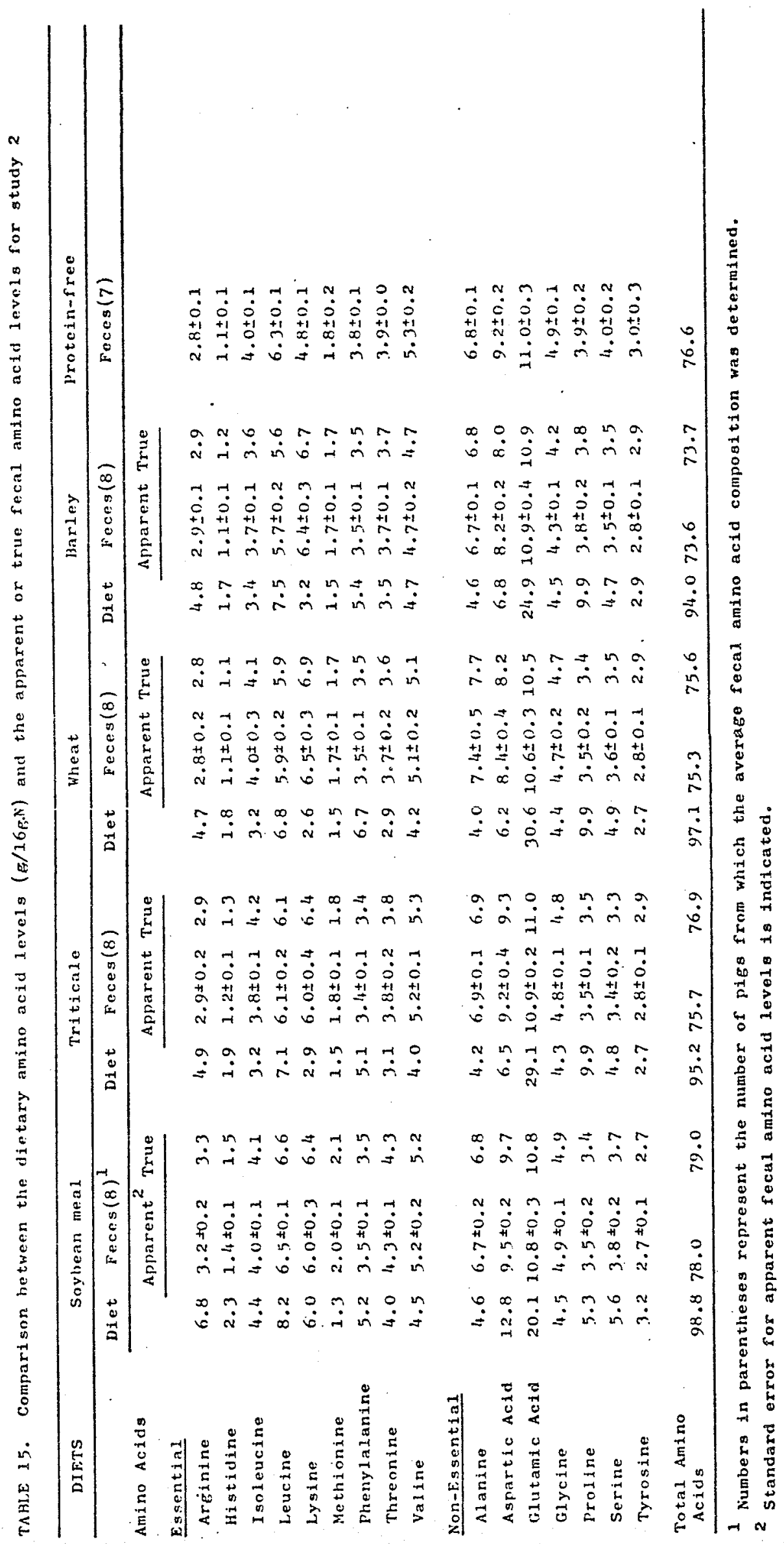


relatively high availability of phonylalanine, glutanic acid, proline and serine (and probably also of arfinine and histidine) is not dependent on the type of protein, i.e. whether animal protein or different plant protein sources are dealt with. It is likely that the microflora degrade these amino acids preferentially. Michel (1961) carried out in vitro experiments to determine the relative susceptibility of free amino acids to degradation by the cecal flora of the pigr. According to his findings one might divide anino acids into 3 groups from relatively high to medium to low susceptibility to microbial degradation : l) arginine, histidine, aspartic acid, glutamic acid and serine were easily degraded, 2) threonine, isoleucine, leucine and alanine were internediate in susceptibility to degradation, with respect to group 1 and group 3, 3) lysine, methionine, phenylalanine, valine, proline and tyrosine were relatively insusceptible to degradation by the microflora. Michel's observations miłht explain the high availabilities of arginine, histidine, gr. acid and serine (as was found in both studies) but not those of phenylalanine and proline which, in vitro, were found to be relatively insusceptible to microbial defradation. Neither do his observations explain the relatively low availability of aspartic acid from the cereal grains and its relatively higin availability from 
soybean neal (Tables $5,6,8$ and 9).

Combe and pion (1966) determined the amino acid composition $(g / 16 \mathrm{~g})$ of the cecal contents of germ-free and normal rats that were fed a $22 \%$ casein diet. The levels of lysine and alanine were markedly higher in the cecal contents from the normal rat than in the cecal contents from the germ-free rat. Their findjngs could perhaps explain to a certain extent the low availability of alanine, resulting from microbial synthesis, from all four diets tested (Tables $5,6,8$ and 9).

As noted previously, lysine is the indispensable amino acid that is nost limiting in many foods of plant origin especially in cereal grains. Therefore, knowledge of its availability is of primary importance. Lysine was found to be less digestible (either true or apparent digestibility) than total $N$ in triticale, wheat and barley. Its digestibility (or availability) was very similar to that of total $N$ in soybean meal (Tables 4 and 7). Surprisingly, the fecal lysine levels ( $g / 16 g \mathrm{~N}$ ) from soybean meal, triticale, wheat and harley varied only slightly in spite of the large variation in their dietary levels (Table 14 and 15). The latter variation was mainly due to the higher dietary lysine level in soybean neal relative to those in the cereal grains. Lysine, derived from bacterial synthesis, might cause its dietary availability to be underestimated. 
Also, its relatively low susceptibility to bacterial dexradation could result in its availability to be. underestimated relative to those of the other aliino acids. Assuming that the true lysine availability (or digrestibility) is similar to that of total $N$ for the diots tested, about $0 . I^{I}, 0.7^{I}, L . O^{1}$ and $1.0^{1} g$ of fecal lysine would be derived from bacterial synthesis for soybean meal, triticale, wheat and barley respectively in study 2 (Table 15; Appendix, Table 12). The anount of bacterial lysine synthesized is likely to depend to a certain extent on the type of diet fed but it seens unlikely that $7^{2}$ to $10^{2}$ times as much bacterial lysine will be synthesized when the animals are fed the cereal grains as when they are fed soybean meal. Therefore, irrespective of bacterial synthesis of lysine, the avajlability of 1ysine from the protein fraction of the cereal grains has to be lower than that of soybean meal. In general, the dietary levels $(g / 16 \mathrm{~g} \mathrm{~N})$ of the different amino acids from soybean meal and the cereal grains differed widely (Table 14 and 15). However, the fecal levels $(\xi / 16 \mathrm{~g} N)$ were more or less similar. These findings seem to indicate that the indigestible $N$

\footnotetext{
$1\left(\frac{\text { True fecal lysine level }(\mathrm{g} / 16 \mathrm{gN})-1 \text { ietary } 1 \mathrm{ysine} \text { level }(\mathrm{G} / 16 \mathrm{gN})}{\text { True fecal lysine level }(\mathrm{g} / 16 \mathrm{gr})}\right) \times$ ( total amount of fecal lysine from dietary source $(g)$ ) 2 $0.7 / 0.1=7 ; 1.0 / 0.1=10$.
} 
fractions from soybean meal, triticale, wheat and barley differ only in total quantity and not in composition (Table 14 and 15). porhaps one minht divide the dietary $N$ of plant protein into 2 components as to their amino acid availability and composition: 1) fraction A, from which the amino acids are readily available and from which the amino acid composition is specilic for cach type ot plant protein, 2) fraction 13 , from which the amino acids are not readily available and from which the amino acid composition is more or less similar for the types of plant proteins that were tested. This fraction B would increase from soybean meal to triticale to wheat and to barley as a percentage of the total dietary $N$ fraction.

One of the reasons, apart from other factors, that could cause differences in arino acid availabilities between different kinds of protein is 1 ikely to be the levels of basic and aromatic amino acids in these proteins. Trypsin catalyzes the hydrolysis or peptide bonds whose. carbonyl function is donated by a basic anino acid such as arginine or lysine. Chymotrypsin prefers to catalyze the hydrolysis of peptide linkages involving the aromatic amino acids, particularly phenylalanine and tyrosine. Therefore, in all likelihood, the hifrher the levels $(g / 16 \mathrm{~g} N)$ of basic and aromatic amino acias in a protein the easier (and more complete) the digestion of that protein. The peptide bond at the lysine position is 
resistant to hydrolysis by trypsin in case lysine is cross-linked to other amino acids (pape 29). From these considerations it may be seen that the degree of digestion of a certain type of protein may depend on its level. of available lysine. Consequently, the level of unavailable lysine, as to peptide digrestjon by trypsin, would in turn decrease the anino acid avajlabilities of other anino acids because of a less complete direstion of the protein. Cross-linked lysine inight well be one of the factors that resulted in the indigrestibility of protein fraction $\beta$ (page 76$)$.

Methionine, the limiting amino acid in soybean protein, also seens to be its least available essential amino acid (Tables 5, 6, 8 and 9). This was confirued by cho and Bayley (1970). The true fecal level (g/16 g N) was marked]y higher than the dietary level of soybean meal. i.e. by $46 \%(1.9 / 1.3)$ in study 1 and by $60 \%(2.1 / 1.3)$ in study 2 (Table 14 and 15). In general, the true fecal methionine levels were only slifhtly higher than the dietary methionine levels regarding the cereal grains (Table 1 it and 15). The question as to why methionine is less available in soybean meal relative to the other anino acids remains to be answered.

The total amino acid levels $(\xi / 16 \mathrm{~g} N)$ for diets and feces represent the recovery of amino acid $N$ (as a percentage of total $\mathrm{N}$ determined by the kjeldahl 
procedure) on the assumption that each amino acid contains $16: 0 \mathrm{~N}$ (Table 14 and 15). However, the percentare of $N$ varies from $32.16 \%$ for arginine to $7.73 \%$ for tyrosine. Never-theless, total amino acid levels from the diets and their feces have been calculated when expressed as $f$ amino acid N/I6 g $N$ (Appendix, Table 15 and 16). Soybean meal was found to contain more $N$ from amino acid $N$ than the cereal grains. Approximately 83 and $75^{\circ}$ of the total $N$ was accounted for by amino acid $N$ in soybean rieal and the cereal grains respectively. The recovery of fecal atlino acid $\mathrm{N}$ was about the same tor the feces from soybean neal and the cereal frains and ranged in between 61.7 and $66.1 \%$ in study 1 and 61.4 and $64.9 \%$ in study 2. The lower fecal than dietary amino acid $N$ recovery might have been due to : 1) the formation of bacterial by-products from amino acids in the gut which are not recovered by amino acid analysis and/or, 2) the non-recoverable dietary $N$ compounds, in case these are absorbed to a lesser extent than the recoverable dietary $N$ compounds, would be present at more concentrated levels in the feces than in the diet. Inclusion of ammonia levels would raise the recovery by about 5 to $10 \%$ in the diets and their feces (Appendix, Table 15 and 16). 


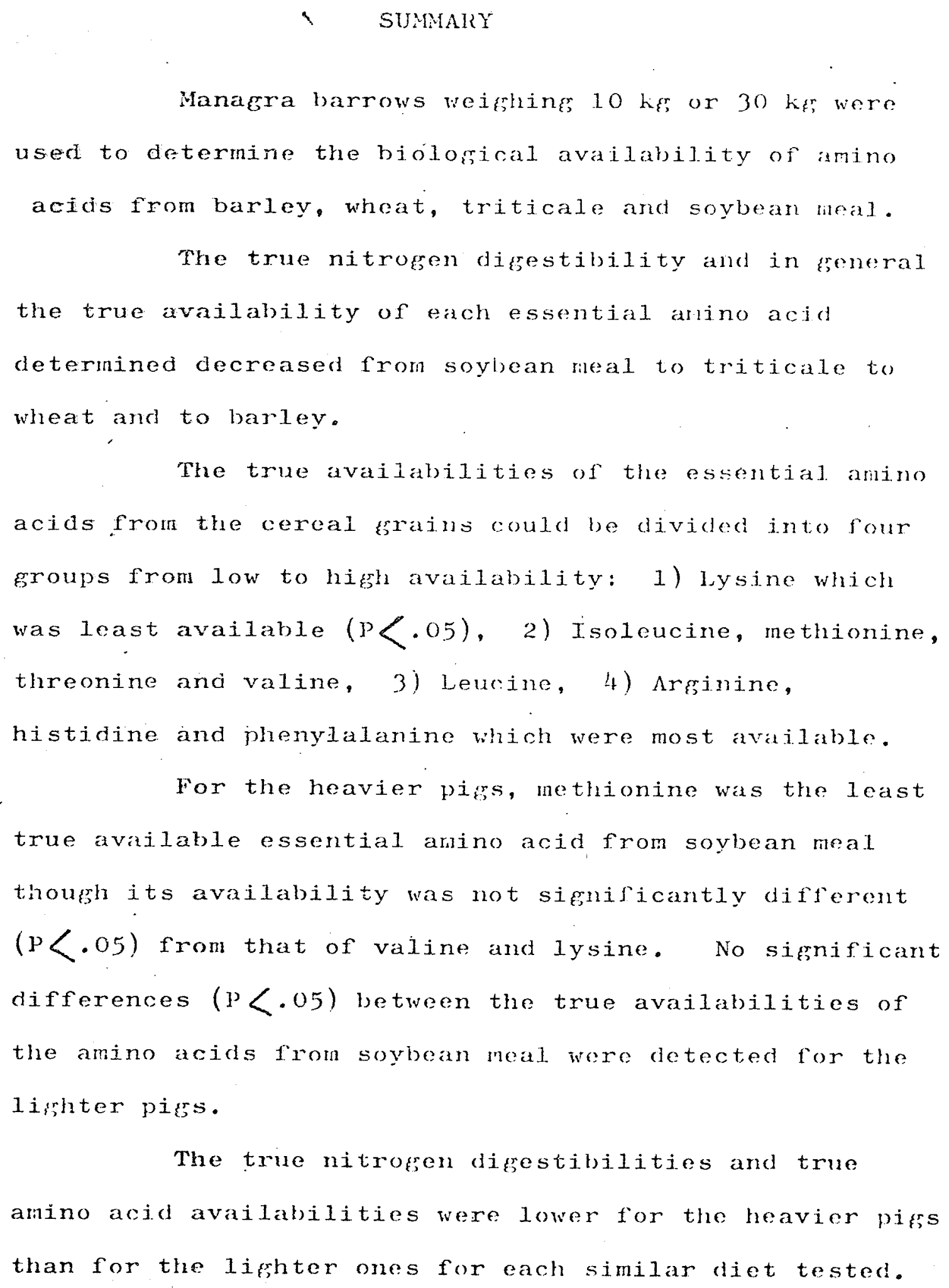

The true nitrogen digestibilities and true amino acid availabilities were lower for the heavier pigs than for the lighter ones for each similar diet tested. 
This was especially the case for lysine from tho coreal grains. Corrections ror metabolic focal nitropen and amino acid excretion, by equalizing the intake or dry matter excretion of the protein-free diet to that of each test diet, resulted in more comparable true nitrogen digestibilities and true amino acid availabilities. However, the corrections railed to make the true availability estinates, in particular those of lysine from the cereal grains, more comparable. This was due to the fact that the corrected metabolic fecal lysine excretion did not increase in the same proportion as total nitrogen from the lighter to the heavier pigs. Hesides, the relatively large differences in truc lysine availability. (and other low available amino acids) from the cereal grains between the lighter and heavier pigs might also be attributed partly to the relatively smaller differences that were obtained between the true nitrogen digestibilities for each of the cereal grains.

The relatively high availability of phenylalanine, Elutamic acid, proline and serine (and prohably also of arginine and histidine) from all diets tested mirht be due to bacterial degradation in the gut.

The low availability of lysine from the cereal grains, though its availability nay be underestimated to a certain extent due to bacterial synthesis, seems to be related to the presence of cross-1inked lysine in these feeds. 
Perhaps one misht divide the dietary nitrogen of plant proteins into two components as to their abino acid availability and composition: 1) Fraction A, from which the amino acids are readily available and from which the amino acid composition is specific for cach type of plant protein, 2) Fraction 13, from which the amino acids are not readily available and from which the anino acid composition is more or less similar for the types of plant proteins that were tested. This fraction $B$ would seen to increase from soybean meal to triticale to wheat and to barley as a percentage of the total dietary nitrogen fraction. 


\section{BI BLIOGRAPHY}

Abrams, G.D., H. Hrauer and H. Sjrinz. 1963. Influence of normal microbial flora on mosal. morphology and cellular senewal in the ileum. A comparison of germ-free and conventional mice. Lab. Invest. 12: 355-359.

Anderson, R.F., R.A. Rhodes, G.I.N. Nelson, M.C. Shekleton, A. Barreto, Jr. and M. Arnold: 1958. Lysine, nethionine and tryptophan content of microorganisms. I. Bacteria. J. Bact. 76: 131-135.

Barnes, R.II. and E. Kiwong. 1964. Methionine absorption and utilization from soybean protein and the effect of soybean trypsin inhibitor A study of amino acid availability. In The Role of the gastrointestinal. Tract in 'rotein Metabol ism, pp.4I-5h. H.N. Hunro, ed. Academic press, New York.

Be11, J.M. 1948 . An adjustable cylindrical cage for use in metabolism studies with young pigs. J. Nutr. 35: 365-369.

Bergen, W.G. and D.H. Purser. 1968 .

Effect of feeding different protein sources on plasma and gut amino acids in the growing rat.

J. Nutr. 95: 333-340.

Bjarnason, J. and K.J. Carpenter. 1969. Mechanism of heat danage in proteins. 1. Models with acylated lysine units. Brit. J, Nutr. 23: 859-868.

Bjarnason, J. and K.J. Carpenter. 1970. Mechanism of lieat danage in proteins. 2. Chenical changes in pure proteins. Brit. J. Nutr. 24: 313-329.

Boctor, A.M. and A.E. Harper. 1968. Measurement of available lysine in heated and unheated foodstufis by chemical and biological methods. J. Nutr. 94:289-296.

Calhoun, U.K., F.N. Hephurn and w. B. Hradley. 1960. The availability of lysine in wheat, flour, bread and gluten. J. Nutr. 70: 337-347.

Carlson, K.H. and H.S. Bayley. 1970.

Nitrogen and amino acids in the feces of young pigs receiving a protein-free diet and diets containing graded levels of soybean oil meal or casein. J. Nutr. 100: 1353-1362. 
Caxpenter, K.J. 1960 .

The estimation of available lysine in animal-protein

foods. biochem. J. 77:604-610.

Carpenter, K.J. and B.E. March. 1961.

The availability of lysine in frroundnut biscuits

used in the treatment of kwashiorkor. 2.

Brit. J. Nutr. 15:403-409.

Cho, C.Y. and H.S. Hayley. 1.970.

Evaluations of rapeseed and soybean meals as protein

sonrces for swine: Apparent digestibilities of

amino acids. Canad. J. Anim. Sci. 50: 521-529.

Combe, E., E. Penot, H. Charjier and E. Sacquet. 1965.

Métabolisme du rat "germ-freo".

Ann. Biol. Anim. Biochin. Biophys. 5: 183-206.

Combe, E. and R. Pion. 1966.

Note sur la composition en acides aminés du contenu

de caecum de rats axeniquas et de rats temoins.

Ann. Biol. Anim. Biochim. Biophys. 6: 255-259.

Cranwe11, P.D. 1968.

Microbial fermentation in the alimentary tract of the pig. Nutr. Abstr. Kev. 38: 721-730.

Crompton, D.W.T. and M.C. Nesheim. 1969.

Amino acid patterns during digestion in the small

intestine of ducks. J. Nutr. 99:43-50.

de Muelenaere, H.J.H., M.L. Chen and A.E. Harper. 1967.

Assessment of factors influencing estimation or

availability of threonine, isoleucine and valine in

cereal products. J. Agr. Food Chem. 15: 318-323.

Denton, A.E. and C.A. Elvehjem. 1954.

Amino acid concentration in the portal vein after

ingestion of amino acids. J. Hiol. Chern. 206: 455-160.

Evrard, F. P.P. Hoet, II, Eyssen, H, Charlier and E. Sacquet. 1964.

Faecal 1 ipids in germ-free and concentional rats. Brit. J. Exp. pathol. 45:409-414.

Ford, J.E. 1964 .

A microbiological nethod for assessing the nutritional value of proteins. 3. Further studies on the moasurement of available anino acids. Brit. J. Nutr. 18: $149-460$. 
Giovanetti, P.M., S.C. Stothers and R.J. Parker. 1970. Coprophagy prevention and availability of anino acids in wheat for the krowing rat.

Canad. J. Anim. Sci. 50: 269-277.

Gordon, H.A. and B.S. Wostmann. 1960. Morphological studies on the germ-free albino rats. Anat. Rec. 137: 65-67.

Gordon, H.A. and E. Bruckner-Kardoss. 1961. Fffect of nornal microbial flora on various tissue elements of the silall intestine. Acta Anat. 44: 210-219.

Gupta, J.I., A.M. Dakroury, A.E. Harper and C.A. EIvehjem. 1958. Biological availability of lysine. J. Nutr. 64: 259-270.

Harmon, B.G., D.H. Becker and A.H. Jensen. 1967. Fffect of microbial. flora on nitrogen excretion products (Abstract). J. Anin. Sci. 26: 907.

Harmon, B.G., D.E. Becker, A.H. Jensen and D.ll. Baker. 1968. Influence of microbiota oì netabolic fecal rituregen in rats. J. Nutr. 96: 391-396.

Hi11, R.1.. .1965. Hydrolysis of proteins. Adv. Protein Chem. 20: 37-107.

Horowitz, W. ed. 1965. Official Methods of Analysis of the Association of Agricultural Chomists. Ioth ed. A.O.A.C., Washington, I.C.

Kuiken, K.A. and C.M. Lyman. 1948. Availability of amino acids in some foods. J. Nutr. 36: 359-368.

Larson, N.1. and F.G. “Hi11. 1960. Amine formation and metabolic activity of microorganisms in the ileum of young swine fed chlortetracycline.

Lepkovsky, S., F. Furuta, K. Oxone and T. Koike. 1966. The proteases, anylase and lipase of the pancreas and intestinal contents of germ-free and conventional rats. Brit. J. Nutr. 20: 257-261. 
Levenson, S.M. and 13. Tennant. 1963.

Contributions of intestinal microflora to the. nutrition of the host animal. Some metabolic and nutritional studies with germ-free animals. Fed. Proc. 22: 109-12:.

LIoyd, L.E., D.G. Dale and E.W. Crampton. 1958. The role of the caecum in nutrient utilization by the pig. J. Anim. Sci. 17: 68/t-691.

Luckey, T.D. 1963. Gerinfree life and Gnotobiologry.

Mahlex, H.R. and F.H. Cordes. 1966. Basic Biolorical Chemistry. Harper \& Row, Jublishers, New York.

Meyer, J.H. 1956. Influence of dietary fiber on metabolic and endogenous nitrogron excretion. J. Nutr. 58:407-413.

Michel, M.C., 1961. Activité métabolique de la flora totale isolée de l'intestin de porc: Ann. Biol. Anin. Biochim. Biophys. 1: 16-27.

Miche1, M.C. 1966. Métabolisine de la flora intestinal du porc degradation des formes $L$ and $I$ ) des acides aminés. Ann. Biol. Anin. Biochim. Biophys. 6: 33-46.

Mitchel1, H.H. and M.H. Bert. 1954. The determination of metabolic fecal nitrogen. J. Nutr. 52: 483-497.

Nasset, E.S., P. Schwarty and II.V. Weiss. 3.955. The digrestion of proteins in vivo. J. Nutr. 56: 83-94.

Nasset, E.S. and J.S. Ju. 1961. Nixture of endorenous and exogrenous protein in the alimentary tract. J. Nutr. 74: 461-465.

Nasset, E.S. 1965. Role of the dimestive system in protein metabolism. Fed. Proc. 24: 953-958.

Nesheim, M.C. and K.J. Carpenter. 1967. The digestion of heat-damaged protein. Brit. J. Nutr. 21: 399-411. 
Payne, W.L., G.F. Combs, R.R. Kifer and I.G. Snyder. 1968 . Investiqution of protein quality: ilual recovery of anino acids. Fed. Jroc. 27: 1199-1203.

SaIter, D.N. and M.E. Coates. 1971 . The influence of the microflora of the alimentary tract on protein digestion in the chick. Brit. J. Nutr. 26:55-69.

Snook, J.T. and J.H. Heyer. 1964a. Response of digestive enzymes to dietary protein. J. Nutr. 82: $409-414$.

Snook, J.T. and J.H. Meyer. $1964 \mathrm{~b}$. Effect of diet and digestive processes on proteolytic enzynes. J. Nutr. 83:94-102.

Snook, J.T. 1965. Fffect of diet on intestinal proteolysis. Fed. Proc. 24: 941-945.

Stee1, R.G.D. and J.H. Torrie. 1960. Principles and procedures of statistics. NcGraw-Hill book Company, New York.

Stott, J.A. and II. Sinith. 1966. Microbiolorical assay of protein quality with Tetrahymena pyriformis $W$. 4. Measurement of available lysine, methionine, arginine and histidine. Brit. J. Nutr. 20:663-673.

TwombIy, J. and J.H. Meyer. 1961. Endogenous nitrogen secretions into the digestive tract. J. Nutr. 7/4: 453-460.

Valle-Riéstra, J. and R.H. Barnes. 1970. Digestion of heat-damaged egg albumen by the rat. J. Nutr. 100: 873-882.

Whiting, $F$. and 1.N. Bezeau. 1957. The metabolic fecal nitrogen excretion of the pig as influenced by the amount of fibre in the ration and by body weight. Canad. J. Anim. Sci. 37: 95-105. 
APPENDTX Table 1. Analysis of variance between treatments for study 1: Mean scuares for apparent amino acid availabilities and apparent nitrogen and dry matter dipestibility

Item

Source of Variation

legrecs of freedom

Essential.

Arginine

Histidine

Isoleucine

Leucine

Lysine

Methionine

Phenylalanine

Threonine

Valine

Non-Issentia1

Alanine

Aspartic Acid

Glutamic Acid

Glycine

Proline

Serine

Tyrosine

Nitrogren

Dry Matter

$$
127.8^{x x}
$$
$78.1^{\mathrm{xx}}$

$139.7^{x x}$

$$
58.2^{\mathrm{xx}}
$$$$
356.7^{\mathrm{xx}}
$$$$
12.0
$$$$
31.1^{\mathrm{x}}
$$$$
184.3^{x x}
$$$$
45.9^{x}
$$

$153.3^{\mathrm{xx}}$

$368.0^{x x}$

$50.7^{x x}$

$73.2^{x x}$

$33.5^{\mathrm{xx}}$

$98.2^{x x}$

$65.4^{x \times}$

$72.0^{x x}$

3.9 $\begin{array}{cc}\text { Squares } & \text { Pigs/Squar } \\ 1 & 6 \\ \text { (Mean } & \text { squares) }\end{array}$

$\begin{array}{cc}\text { Squares } & \text { Pigs/Squar } \\ 1 & 6 \\ \text { (Mean } & \text { squares) }\end{array}$

0.1

$20.2^{x}$

8.5

27.1

4.3

21.4

1.6

57.5

0.8

5.2

47.7

16.4

15.8

3.5

23.7

25.8

5.8

13.5

1. 5

3.8

1.0

5.8

2.6

35.2

25.1

7.0

29.1

7.9

13.1

31.9

1. 1

23.2

0.6
10.5

13.5

22.1

15.4

48.2

25.0

14.1

20.3

16.9

25.5

24.5

4.6

19.4

7.4

12.9

21.5

11.6

9.4
6.1

6.0

11.6

7.9

42.8

16.6

6.3

15.7

1.0 .5

14.9

16.8

3.6

11.4

3.3

7.3

11.3

9.0

5.4

$\begin{array}{ll}x & (p<0.05) \\ x x & (p<0.01)\end{array}$ 
APPFNUIX Table 2. Analysis of variance between treatments for study 1: Mean squares for true amino acjd availabilities and true nitrogen digestibility

I tein

Source of variation

Degrees of

freedom

Essential

Arginine

Iistidine

Isoleucine

leucine

Lysine

Methionine

Phenylalanine

Threonine

Valine

Non-Fssential

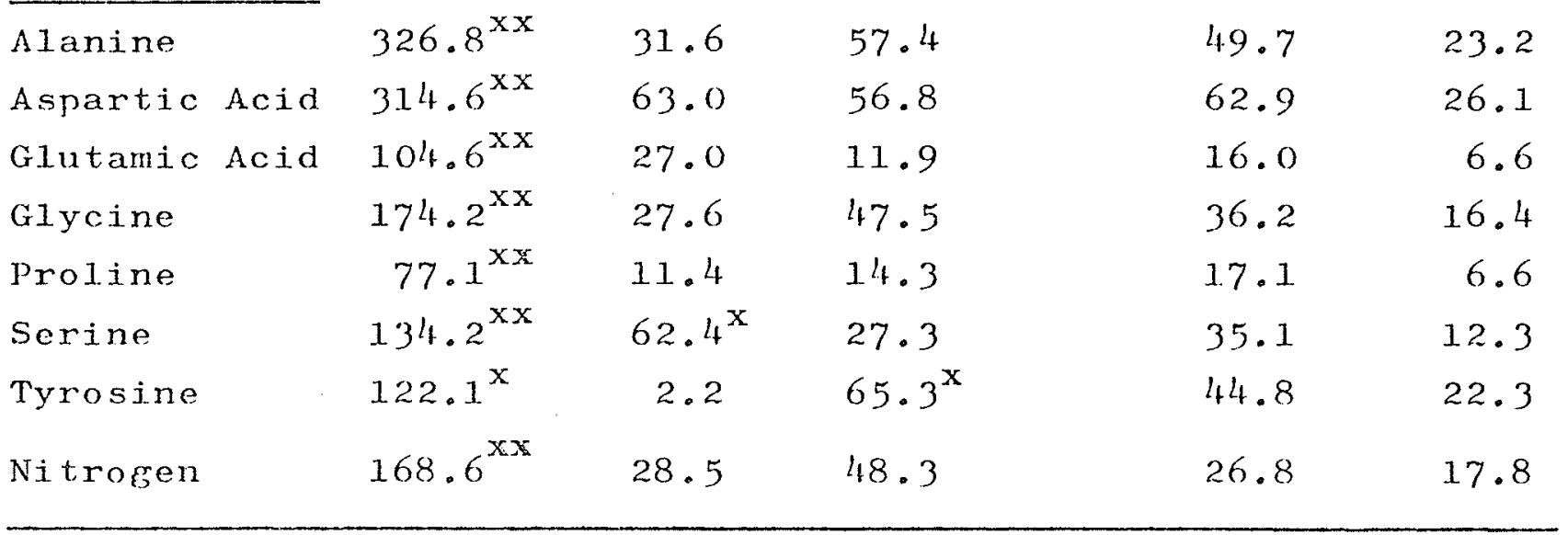

$\begin{array}{ll}x & (1<0.05) \\ x \times 0.01)\end{array}$

Treatments Squares Pigs/Square Periods/Square Frror $3 \quad 1 \quad 6 \quad 6$

13

$$
\text { (Mear. squares) }
$$

$\begin{array}{lrlll}196.2^{\mathrm{xx}} & 0.2 & 72.0^{\mathrm{xx}} & 30.7 & 14.5 \\ 142.9^{\mathrm{xx}} & 1.7 & 87.2^{\mathrm{xx}} & 43.2^{\mathrm{x}} & 13.3 \\ 230.2^{\mathrm{xx}} & 1.9 & 52.3^{\mathrm{x}} & 39.2 & 19.6 \\ 142.7^{\mathrm{xx}} & 13.1 & 45.5^{\mathrm{x}} & 30.3 & 13.7 \\ 527.4^{\mathrm{xx}} & 12.3 & 80.9 & 90.3 & 48.5 \\ 193.6^{\mathrm{x}} & 0.6 & 188.0^{\mathrm{x}} & 50.7 & 44.0 \\ 101.2^{\mathrm{xx}} & 14.6 & 27.9^{\mathrm{x}} & 31.4^{\mathrm{x}} & 9.6 \\ 214.0^{\mathrm{xx}} & 55.7 & 40.8 & 56.3 & 22.8 \\ 140.4^{\mathrm{xx}} & 13.0 & 45.2 & 40.5 & 23.1\end{array}$


APIPNDTX Table 3. Analysis of variance between treatments for study 2: Mean squares for apparent amino acid availabilitios and apparent nitrogen and dry matter digestibility

Item

Source of variation

Degrees of

freedom

Essential

Arginine

listidine

Isoleucine

Leucine

Lysine

Methionine

Phenylalanine

Threonine

Valine

Non-Fisentia1

Alanine

Aspartic Acid

Glutamic Acid

Glycine

proline

Serine

Tyrosine

Nitrogen

Dry Matter
Treatments

3
Periods

3
Pi. $\xi s$

7
Error

18

$$
\text { (Mean squares) }
$$

$\begin{array}{llrr}64.1^{\mathrm{xx}} & 17.9^{\mathrm{x}} & 3.2 & 5.8 \\ 45.3^{\mathrm{xx}} & 14.1 & 8.0 & 8.6 \\ 90.8^{\mathrm{xx}} & 58.5^{\mathrm{xx}} & 7.2 & 10.1 \\ 40.1^{\mathrm{xx}} & 39.5^{\mathrm{xx}} & 3.3 & 7.5 \\ 653.1^{\mathrm{xx}} & 135.5^{\mathrm{x}} & 20.2 & 38.3 \\ 28.3^{\mathrm{n}} & 74.7^{\mathrm{xx}} & 11.7 & 12.0 \\ 29.8^{\mathrm{xx}} & 31.7^{\mathrm{xx}} & 4.3 & 5.6 \\ 75.5^{\mathrm{xx}} & 46.9^{\mathrm{x}} & 4.6 & 12.1 \\ 46.2^{\mathrm{xx}} & 67.6^{\mathrm{xx}} & 12.2 & 7.7\end{array}$

$124.0^{x x}$

$146.2^{x x}$

12.1

19.3

$213.4^{x x}$

$67.7^{\mathrm{x}}$

12.1

19.4

$27.7^{x x}$

$23.7^{\mathrm{xx}}$

2.1

4. 1

34.7

$65 \cdot 9^{\mathrm{xx}}$

4.5

11. 1

$25.1^{x x}$

$55.3^{x x}$

18. $5^{\mathrm{xx}}$

3.1

3.4

$31.5^{\mathrm{xx}}$

0.6

5.7

$79.1^{\mathrm{xx}}$

$47.4 \mathrm{xx}$

3.9

8.2

$61.1^{\mathrm{xx}}$

$59.0^{\mathrm{xx}}$

4.4

9.5

2.6

$39.4^{\mathrm{xx}}$

3.2

6.7

$\begin{array}{ll}x & (P<0.05) \\ & (P<0.01)\end{array}$ 
APpNDIX Table 4. Analysis of variance letween treatments for study 2: Mean squares for true anino acid availabilitics ard true nitrogen djgestibility

Itein

Source of variation

Degrees of

freedom

Essential

Arginine

Histidine

Isoleucine

leucine

Lysine

Methionine

Phenylalanine

Threonine

Valine

Non-Essential

Alanine

Aspartic Acid

Glutanic Acid

Glycine

proline

Serine

Tyrosine

Nitrogen

$\begin{array}{ll}x & (1<0.05) \\ x \times & (p<0.01)\end{array}$
Treathent periods Pigs Frror

3

3

7

18

(Mean squares)

$\begin{array}{lrrr}63.4^{\mathrm{x}} & 33.7^{\mathrm{x}} & 3.7 & 7.0 \\ 43.7^{\mathrm{x}} & 25.3^{\mathrm{x}} & 8.3 & 1.0 .5 \\ 90.2^{\mathrm{xx}} & 105.8^{\mathrm{xx}} & 11.5 & 11.9 \\ 42.9^{\mathrm{x}} & 70.8^{\mathrm{x}} & 6.0 & 8.8 \\ 599.0^{\mathrm{xx}} & 192.9^{\mathrm{x}} & 22.6 & 40.0 \\ 29.4^{\mathrm{x}} & 116.8^{\mathrm{x}} & 17.9 & 15.4 \\ 37.3^{\mathrm{x}} & 58.6^{\mathrm{x}} & 6.7 & 6.6 \\ 75.1^{\mathrm{x}} & 87.8^{\mathrm{x}} & 7.0 & 13.7 \\ 45.1^{\mathrm{x}} & 121.7^{\mathrm{xx}} & 14.3 & 12.3\end{array}$

$171.1^{\mathrm{xx}}$

$222 \cdot 9^{\mathrm{xx}}$

$24 \cdot 5$

19.6

$1.839 .2^{x x}$

85.1

26.4

28.1

$38.4^{\mathrm{xx}}$

$1+3.5^{x x}$

4.5

5.0

39.5

$118.9^{\mathrm{xx}}$

8.8

13.2

$20.3^{x}$

$38.6^{\mathrm{xx}}$

6.2

4.5

$59.1^{x x}$

$61.6^{x x}$

10.3

3.5

$85.1^{x \mathrm{x}}$

$84.5^{x \times}$

5.9

8.9

$65.6^{x x}$

4.9

12.0 
APPENDTX Table 5. Analysis of variance within treatments for study 1: Mean squares for true and apparent anino acid availabilities

\section{Item \\ Source of \\ variation \\ Degrees of \\ freedom \\ True availability}

Soybean meal

Triticale ${ }^{1}$

Triticale repeat ${ }^{2}$

Wheat

Barley

Apparent Availability
Be tween
amino acids

15
Within amino acids (error)

112

\begin{tabular}{rr}
\multicolumn{2}{c}{ (Mean squares) } \\
$37.5^{\mathrm{x}}$ & 37.4 \\
$43.3^{\mathrm{x}}$ & 23.2 \\
$32.4^{\mathrm{xx}}$ & 1.2 \\
$158.0^{\mathrm{xx}}$ & 47.5 \\
$122.5^{\mathrm{xx}}$ & 24.8
\end{tabular}

$\begin{array}{rr}102.8^{x \times} & 8.0 \\ 231.8^{x x} & 8.1 \\ 72.0^{x x} & 0.4 \\ 336.2^{x x} & 30.8 \\ 254.7^{x x} & 10.2\end{array}$


AlPENDIX Table 6. Analysis of variance within treatments for study 2: Mean squares for true and apparent anino acid availabilities

Item

Source of variation

Degrees of

freedom

True Availability

Soybean meal

Triticale

Wheat

Barley

Apparent Availability

Soybean neal

Triticale

Wheat

Barley
Between

amino acids

15

$60.5^{x x}$

$183.1^{\mathrm{xx}}$

$282.3^{x x}$

$232.7^{x x}$

$89.8^{x x}$

$228.0^{x x}$

$344.0^{x x}$

$274.9^{x x}$
Within amino

acids (error)

112

15.1

18.8

27.4

23.6

$x \times(p<0.01)$ 
APPENDIX Table 7. Mean and standard error of the apparent availability of amino acids in study 1 as influenced by the type of diet

\begin{tabular}{|c|c|c|c|c|}
\hline Diets & $\begin{array}{l}\text { Soybean } 1 \\
\text { meal }(8)\end{array}$ & Triticale $(6)$ & Wheat $(8)$ & Barley $(8)$ \\
\hline \multicolumn{5}{|l|}{ Amino acids } \\
\hline \multicolumn{5}{|l|}{ Essential } \\
\hline Arginine & $93.2 \pm 0.6$ & $88.6 \pm 1.0$ & $86.8 \pm 1.5$ & $82.5 \pm 1.1$ \\
\hline Histidine & $91.6 \pm 0.7$ & $89.3 \pm 0.8$ & $87.6^{ \pm}-1.5$ & $83.1 \pm 1.3$ \\
\hline Isoleucine & $86.3^{ \pm}-1.0$ & $78.4 \pm 1.1$ & $78.7 \pm 2.0$ & $72.1 \pm 1.3$ \\
\hline Leucine & $87.5 \pm 0.9$ & $82 \cdot 5 \pm 1.0$ & $82.4 \pm 1.8$ & $79.1 \pm 0.9$ \\
\hline lysine & $82.5 \pm 1.0$ & $66.6 \pm 1.8$ & $61.6 \pm 3.5$ & $57 \cdot 6 \pm 1 \cdot 3$ \\
\hline Methionine & $78.5 \pm 1.7$ & $78.0^{+} 1.2$ & $77.8 \pm 2.3$ & $74.5 \pm 1.4$ \\
\hline Pheny 1 alanine & $88.4 \pm 0.9$ & $85.6 \pm 0.9$ & $86.4+1.5$ & $82.5^{ \pm}-0.8$ \\
\hline Threonine & $86.0 \pm 1.0$ & $71 . .1 \pm 1.7$ & $75.0 \pm 1.8$ & $72.4^{ \pm}-1.3$ \\
\hline Valine & $84.3 \pm 1.0$ & $79.1 \pm 1.0$ & $77.8 \pm 2.0$ & $77.2 \pm 1.0$ \\
\hline \multicolumn{5}{|l|}{ Non-Essential } \\
\hline Alanine & $81.9 \pm 1.1$ & $72.9 \pm 1.2$ & $70.6 \pm 2.3$ & $66.1 \pm 1.3$ \\
\hline Aspartic Acid & $89.0 \pm 0.8$ & $69.2 \pm 1.8$ & $70.6 \pm 2.2$ & $71.8 \pm 1.3$ \\
\hline Glutamic Acid & $92.5 \pm 0.7$ & $92.9 \pm 0.6$ & $94.1 \pm 0.8$ & $88 \quad 4 \pm 0.6$ \\
\hline Glycine & $83.7 \stackrel{+}{-1.2}$ & $78.5^{ \pm}-1.1$ & $79.1 \pm 20$ & $73.2 \pm 1.1$ \\
\hline Proline & $90.8 \pm 0.8$ & $94.1 \pm 0.5$ & $93.6 \pm 1.1$ & $90.3 \pm 0.3$ \\
\hline Serine & $90.3 \pm 0.7$ & $83.2 \pm 1.0$ & $86.0 \pm 1.4$ & $80.4 \pm 1.1$ \\
\hline Tyrosine & $85.6 \pm 1.2$ & $78.8 \pm 1.1$ & $80.1 \pm 2.1$ & $76.6 \pm 1.1$ \\
\hline
\end{tabular}

1 Numbers in parentheses indicate the number of determinations for which the mean and standard error were determined. 
AJPENDIX Table 8. Mein and standard error of the true availability of amino acids in study 1 as influenced by the type of diet

\begin{tabular}{|c|c|c|c|c|}
\hline Diets & $\begin{array}{l}\text { Soybean } \\
\text { meal }(8)\end{array}$ & Triticale (6) & Wheat $(8)$ & Barley (8) \\
\hline \multicolumn{5}{|l|}{ Amino acids } \\
\hline \multicolumn{5}{|l|}{ Essential } \\
\hline Arginine & $98.4 \pm 1.4$ & $98.5 \pm 2.3$ & $94.1 \pm 2.5$ & $91.4 \pm 1.8$ \\
\hline Histidine & $97 \cdot 9 \pm 1.5$ & $99.1 \pm 2.1$ & $94.7 \pm 2.4$ & $93.2 \pm 2.4$ \\
\hline Isoleucine & $95.2 \pm 2.2$ & $95.8 \pm 0.9$ & $89.2 \pm 2.4$ & $84.7 \pm 1.7$ \\
\hline Leucine & $95.7 \pm 2.0$ & $96.6 \pm 0.9$ & $91.2 \pm 2.2$ & $88.7 \pm 1.5$ \\
\hline Lysine & $94.9 \pm 2.2$ & $94.4 \pm 3.2$ & $80.8 \pm 3.83$ & $77.1 \pm 1.9$ \\
\hline Methionine & $94.5 \pm 4.0$ & $97.0 \pm 2.9$ & $89.8 \pm 2.9$ & $87.3 \pm 2.4$ \\
\hline Phenylalanine & $95.8 \pm 1.9$ & $96.5 \pm 0.9$ & $92.4 \pm 1.7$ & $90.1 \pm 1.3$ \\
\hline Threonine & $95.4 \pm 2.1$ & $94.8 \pm 2.8$ & $87.3 \pm 2.2$ & $85.5 \pm 1.9$ \\
\hline Valine & $94.5 \pm 2.2$ & $95.6 \pm 1.1$ & $89.0 \pm 2.6$ & $87.6 \pm 1.6$ \\
\hline \multicolumn{5}{|l|}{ Non-Essentia1 } \\
\hline Alanine & $94.1 \pm 2.3$ & $94.4 \pm 1.8$ & $84.1 \pm 2.6$ & $80.6 \pm 1.9$ \\
\hline Aspartic Acid & $96.6 \pm 1.8$ & $94.5 \pm 3.2$ & $84.6 \pm 2.8$ & $85.4 \pm 2.0$ \\
\hline Glutamic Acia & $97.8 \pm 1.5$ & $98.7 \pm 1.4$ & $97 \cdot 0^{ \pm}-1 \cdot 1$ & $93.3^{ \pm}-1.0$ \\
\hline Glycine & $94.0 \pm 2.4$ & $94.5 \pm 0.9$ & $88 \cdot 3 \pm 2 \cdot 3$ & $84.3 \pm 1.5$ \\
\hline Proline & $96.8 \pm 1.7$ & $98.2 \pm 0.4$ & $96 \cdot 3 \pm 1 \cdot 3$ & $93.2 \pm 0.5$ \\
\hline Serine & $96.9 \pm 1.7$ & $96.8 \pm 2.2$ & $92.8 \pm 1.8$ & $89.9 \pm 1.7$ \\
\hline Tyrosine & $95.0 \pm 2.3$ & $95.1 \pm 1.1$ & $90.3 \pm 2.7$ & $87.6 \pm 1.7$ \\
\hline
\end{tabular}

1 Numbers in parentheses indicate the number of determinations for which the rean and staudard error were determined. 
APPENITX Table 9. Mean and standard error of the apparent availability of amino acias in study 2 as influenced by the type of diet

\begin{tabular}{|c|c|c|c|c|}
\hline Diets & Soybean meal & Triticale & Wheat & Bar]ey \\
\hline \multicolumn{5}{|l|}{ Amino acids } \\
\hline \multicolumn{5}{|l|}{ Essential } \\
\hline Arginine & $94.7 \pm 0.7$ & $92.2 \pm 0.7$ & $91.2 \pm 0.9$ & $88.1 \pm 1.2$ \\
\hline llistidine & $93.1 \pm 0.7$ & $91.6 \pm 1.1$ & $90.8 \pm 1.3$ & $87.3 \pm 1.1$ \\
\hline Isoleucine & $89.2 \pm 0.9$ & $84.0 \pm 1 . .4$ & $82.0 \pm 1.4$ & $79.1 \pm 1.5$ \\
\hline Leucine & $90.9 \pm 0.8$ & $88.6 \pm 1.1$ & $86.9 \pm 1.2$ & $84.9 \pm 1.3$ \\
\hline Lysine & $88.6 \pm 1.0$ & $72.5 \pm 2.2$ & $61.3 \pm 3.1$ & $60.1 \pm 2.6$ \\
\hline Methionine & $81.7 \pm 1.1$ & $83.5 \pm 1.1$ & $81 \cdot 7 \pm 1.8$ & $77.4 \pm 1.9$ \\
\hline Phenylalanine & $91.7 \pm 0.7$ & $91.1 \pm 0.9$ & $89.3 \pm 1.2$ & $87.2 \pm 1.1$ \\
\hline Threonine & $88.0 \pm 0.9$ & $83.7 \pm 1.4$ & $81.1 \pm 1.3$ & $78.7 \pm 1.6$ \\
\hline Valine & $87.2 \pm 1.0$ & $82.9 \pm 1.6$ & $81.9 \pm 1.5$ & $90.9 \pm 1.5$ \\
\hline \multicolumn{5}{|l|}{ Non-Essential } \\
\hline Alanine & $83.3 \pm 1.2$ & $77.8 \pm 2.0$ & $71.6 \pm 2.4$ & $71.1 \pm 2.0$ \\
\hline Aspartic $\Lambda$ cid & $91.4 \pm 0.7$ & $80.5 \pm 2.4$ & $80.2 \pm 1.6$ & $76.6 \pm 1.7$ \\
\hline Glutamic Acid & $93.9 \pm 0.6$ & $95.0 \pm 1.0$ & $94.8 \pm 0.7$ & $91.5 \pm 1.0$ \\
\hline G.lycine & $87.5 \pm 0.9$ & $85.2 \pm 1.5$ & $83.8 \pm 1.5$ & $81.2 \pm 1.5$ \\
\hline Proline & $92.5 \pm 0.7$ & $95.2 \pm 0.83$ & $94.9 \pm 0.8$ & $92.6 \pm 0.8$ \\
\hline Serine & $92.3 \pm 0.6$ & $90.7 \pm 0.9$ & $89.1 \pm 0.9$ & $85.6 \pm 1.2$ \\
\hline Tyrosine & $90.4 \pm 0.8$ & $86.5 \pm 1.1$ & $84.0 \pm 1.4$ & $81.4 \pm 1.3$ \\
\hline
\end{tabular}

1 Mean and standard error or 8 determinations 
APPENJIX Table 10. Mean and standard error of the true availability of amino acids in study 2 as influenced by the type of diet

\begin{tabular}{|c|c|c|c|c|}
\hline Diets & Soybean meal & Triticale & Wheat & Barley \\
\hline \multicolumn{5}{|l|}{ Amino acids } \\
\hline \multicolumn{5}{|l|}{ Essential } \\
\hline Arginine & $96.0 \pm 1.0$ & $94.1 \pm 0.8$ & $93.1 \pm 1.1$ & $90.1 \pm 1.3$ \\
\hline Histidine & $94.6 \pm 0.7$ & $93.3 \pm 1.2$ & $92.7 \pm 1.5$ & $89.5 \pm 1.2$ \\
\hline Isoleucine & $92.1 \pm 1.5$ & $87.7 \pm 1.6$ & $86.1 \pm 1.8$ & $83.1 \pm 1.7$ \\
\hline Leucine & $93.2 \pm 1.2$ & $91.3 \pm 1.2$ & $89.8 \pm 1.5$ & $87.6 \pm 1.5$ \\
\hline lysine & $91.2 \pm 1.4$ & $77.5 \pm 2.4$ & $67.3 \pm 3.2$ & $65.0 \pm 2.7$ \\
\hline Methionine & $86.3 \pm 1.6$ & $86.8 \pm 1.3$ & $85.7 \pm 2.1$ & $81.5 \pm 2.2$ \\
\hline Phenylalanine & $94.2 \pm 1.2$ & $93.3 \pm 0.9$ & $91.6 \pm 1.4$ & $89.5 \pm 1.3$ \\
\hline Threonine & $91.0 \pm 1.3$ & $87.7 \pm 1.5$ & $85.4 \pm 1.6$ & $82.5 \pm 1.8$ \\
\hline Valine & $90.9 \pm 1.7$ & $86.8 \pm 1.7$ & $85.9 \pm 1.8$ & $84.6 \pm 1.7$ \\
\hline \multicolumn{5}{|l|}{ Non-Issential } \\
\hline Alanine & $89.2 \pm 2.1$ & $82.8 \pm 2.1$ & $77.1 \pm 2.8$ & $76.1 \pm 2.2$ \\
\hline Aspartic acid & $93.9 \pm 1.3$ & $84.9 \pm 2.5$ & $86.8 \pm 2.3$ & $81.1 \pm 1.9$ \\
\hline Glutamic acid & $95.6 \pm 1.1$ & $96.2 \pm 1.1$ & $96.0 \pm 0.9$ & $92.9 \pm 1.1$ \\
\hline G1ycine & $91.0 \pm 1.5$ & $88.7 \pm 1.6$ & $87.5 \pm 1.8$ & $85.0 \pm 1.8$ \\
\hline Proline & $94.8 \pm 1.2$ & $96.4 \pm 0.9$ & $96.2 \pm 1.0$ & $93.9 \pm 1.0$ \\
\hline Serine & $94.6 \pm 1.1$ & $93.1 \pm 1.0$ & $91.6 \pm 1.2$ & $88.5 \pm 1.4$ \\
\hline Tyrosine & $93.1 \pm 1.3$ & $89.7 \pm 1.2$ & $87.5 \pm 1.6$ & $85.0 \pm 1.5$ \\
\hline
\end{tabular}

1 Mean and standard error of 8 determinations 
APPENDIX Table 11. Mean and standard error of the amino acidexcretion (g/day) for study 1 . as influenced by the type of diet

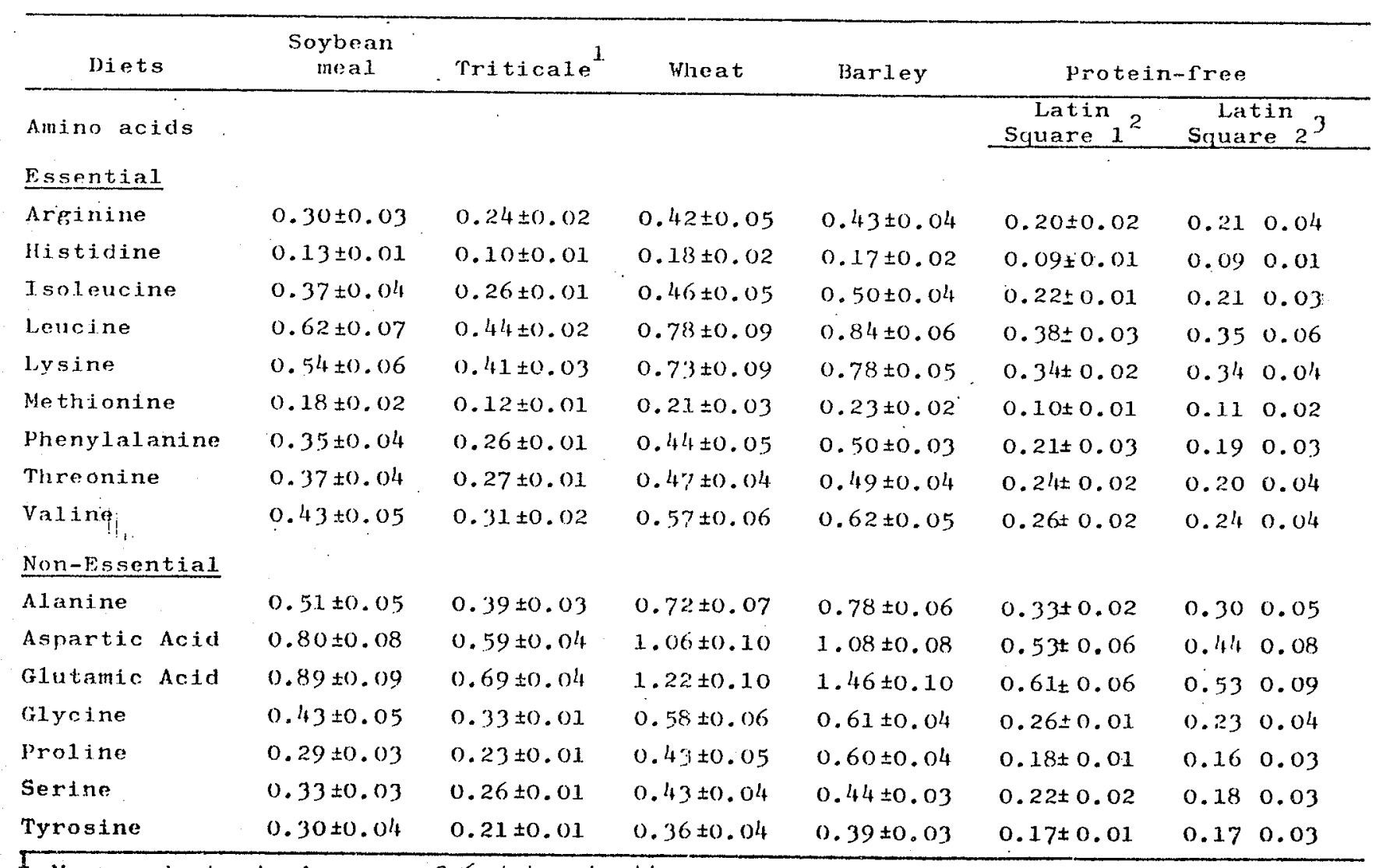

Mean and standard error of 6 deterininations

3 Mean and standard error of 4 .determinations

Mean and standard error of 3 determinations 
APPENDIX Table 12. Mean and standard error of the amino acid excretion $(g)$ by the pigs in study 2 as influenced by the type of diet

\begin{tabular}{|c|c|c|c|c|c|}
\hline Diets & $\begin{array}{c}\text { Soybean } \\
\text { meal }\end{array}$ & Triticale & Wheat & Barley & $\begin{array}{l}\text { Protein- } \\
\text { free }\end{array}$ \\
\hline Amino acids ${ }^{2}$ & & & & & \\
\hline \multicolumn{6}{|l|}{ Essentia1 } \\
\hline Arginine & $0.78 \pm 0.11$ & $0.72 \pm 0.07$ & $0.80 \pm 0.10$ & $1.01 \pm 0.11$ & $0.16 \pm 0.02$ \\
\hline Histidine & $0.32 \pm 0.03$ & $0.32 \pm 0.04$ & $0.32 \pm 0.05$ & $0.39 \pm 0.04$ & $0.06 \pm 0.01$ \\
\hline Isoleucine & $1.03 \pm 0.14$ & $1.01 \pm 0.12$ & $1.10 \pm 0.15$ & $1.24 \pm 0.13$ & $0.22 \pm 0.02$ \\
\hline Leucine & $1.61 \pm 0.21$ & $1.57 \pm 0.18$ & $1.74 \pm 0.24$ & $1.98 \pm 0.22$ & $0.34 \pm 0.03$ \\
\hline Lysine & $1.49 \pm 0.22$ & $1.57 \pm 0.24$ & $1.90 \pm 0.30$ & $2.19 \pm 0.26$ & $0.26 \pm 0.03$ \\
\hline Methionine & $0.48 \pm 0.06$ & $0.46 \pm 0.06$ & $0.52 \pm 0.08$ & $0.60 \pm 0.08$ & $0.10 \pm 0.02$ \\
\hline Phenylalanine & $0.92 \pm 0.12$ & $0.87 \pm 0.09$ & $1.02 \pm 0.13$ & $1.21 \pm 0.12$ & $0.21 \pm 0.03$ \\
\hline Threonine & $1.05 \pm 0.13$ & $0.97 \pm 0.10$ & $1.07 \pm 0.13$ & $1.30 \pm 0.14$ & $0.22 \pm 0.02$ \\
\hline valine & $1.27 \pm 0.17$ & $1.33 \pm 0.17$ & $1.47 \pm 0.20$ & $1.57 \pm 0.16$ & $0.28 \pm 0.03$ \\
\hline \multicolumn{6}{|l|}{ Non-essential } \\
\hline Alanine & $1.68 \pm 0.23$ & $1.80 \pm 0.23$ & $2.23 \pm 0.35$ & $2.34 \pm 0.26$ & $0.37 \pm 0.04$ \\
\hline Aspartic Acid & $2.36 \pm 0.31$ & $2.43 \pm 0.37$ & $2.43 \pm 0.33$ & $2.81 \pm 0.29$ & $0.50 \pm 0.05$ \\
\hline Glutamic Acid & $2.69 \pm 0.35$ & $2.84 \pm 0.40$ & $3.09 \pm 0.41$ & $3.73 \pm 0.43$ & $0.61 \pm 0.07$ \\
\hline Glycine & $1.21 \pm 0.16$ & $1.24 \pm 0.15$ & $1.39 \pm 0.20$ & $1.48 \pm 0.16$ & $0.27 \pm 0.03$ \\
\hline Proline & $0.86 \pm 0.11$ & $0.91 \pm 0.11$ & $0.99 \pm 0.14$ & $1.28 \pm 0.13$ & $0.21 \pm 0.02$ \\
\hline Serine & $0.92 \pm 0.11$ & $0.86 \pm 0.08$ & $1.03 \pm 0.13$ & $1.20 \pm 0.13$ & $0.22 \pm 0.03$ \\
\hline Tyrosine & $0.66 \pm 0.09$ & $0.71 \pm 0.08$ & $0.82 \pm 0.12$ & $0.94 \pm 0.10$ & $0.16 \pm 0.02$ \\
\hline
\end{tabular}

1 2

Mean and standard error of 7 determinations Amino acid excretion expressed as grams per day 
APPENDIX Table 13. Triticale repeat experiment of study 1 : Mean and standard error ${ }^{1}$ of the true and apparent amino acid availability and excretion of amino acids by the pigs (g.)

\begin{tabular}{|c|c|c|c|c|}
\hline \multirow[b]{2}{*}{ Amino acids } & \multicolumn{2}{|c|}{ Availability } & \multicolumn{2}{|c|}{ Fecal Excretion ${ }^{2}$} \\
\hline & Apparent & True & Triticale & $\begin{array}{c}\text { Protein- } \\
\text { free }\end{array}$ \\
\hline \multicolumn{5}{|l|}{ Essential } \\
\hline Arginine & $88.2 \pm 0.4$ & $94.5 \pm 0.3$ & $0.43 \pm 0.02$ & $0.23 \pm 0.02$ \\
\hline Histidine & $87.0 \pm 0.4$ & $93.8 \pm 1.0$ & $0.19 \pm 0.00$ & $0.10 \pm 0.01$ \\
\hline Isoleucine & $83.2 \pm 0.2$ & $91.5 \pm 0.6$ & $0.44 \pm 0.01$ & $0.22 \pm 0.02$ \\
\hline Leucine & $86.0 \pm 0.2$ & $93.7 \pm 0.8$ & $0.75 \pm 0.02$ & $0.41 \pm 0.04$ \\
\hline Lysine & $72.9 \pm 0.3$ & $86.3 \pm 1.0$ & $0.66 \pm 0.01$ & $0.33 \pm 0.04$ \\
\hline Methionine & $78.5 \pm 0.6$ & $90.3 \pm 1.4$ & $0.19 \pm 0.01$ & $0.11 \pm 0.01$ \\
\hline Phenylalanine & $88.1 \pm 0.3$ & $94.5 \pm 0.4$ & $0.44 \pm 0.02$ & $0.24 \pm 0.02$ \\
\hline Threonine & $80.9 \pm 0.3$ & $90.9 \pm 0.2$ & $0.45 \pm 0.01$ & $0.23 \pm 0.01$ \\
\hline Valine & $84.1 \pm 0.4$ & $92.4 \pm 0.2$ & $0.53 \pm 0.02$ & $0.28 \pm 0.02$ \\
\hline \multicolumn{5}{|l|}{ Non-essential } \\
\hline Alanine & $77 \cdot 7 \pm 0.3$ & $88.4 \pm 0.3$ & $0.71 \pm 0.02$ & $0.34 \pm 0.03$ \\
\hline Aspartic $\Lambda$ cid & $79.5 \pm 0.2$ & $91.0 \pm 0.7$ & $1.02 \pm 0.02$ & $0.54 \pm 0.05$ \\
\hline Glutamic acid & $94.7 \pm 0.2$ & $97.6 \pm 0.4$ & $1.16 \pm 0.04$ & $0.62 \pm 0.07$ \\
\hline G1ycine & $84.2 \pm 0.3$ & $92.1 \pm 0.3$ & $0.51 \pm 0.02$ & $0.25 \pm 0.02$ \\
\hline Proline & $94.7 \pm 0.1$ & $97.1 \pm 0.3$ & $0.41 \pm 0.01$ & $0.19 \pm 0.02$ \\
\hline Serine & $87.5 \pm 0.3$ & $94.2 \pm 0.3$ & $0.44 \pm 0.02$ & $0.24 \pm 0.02$ \\
\hline Tyrosine & $83.2 \pm 0.7$ & $92.9 \pm 0.7$ & $0.34 \pm 0.02$ & $0.20 \pm 0.01$ \\
\hline
\end{tabular}

1 Mean and standard error of 3 determinations

2 Amino acid excretion expressed as grans per day 
APPTNDTX Table 1!. Mean ${ }^{1}$ apparent and true essential amino acid availabilities, nitrogen and dry matter digestibility between the test periods in study 2 .

\begin{tabular}{|c|c|c|c|c|}
\hline TEST PFRIONS & I & II & IIII & IV \\
\hline \multicolumn{5}{|c|}{ Apparent availability } \\
\hline \multicolumn{5}{|l|}{ Amino acids } \\
\hline Arginine & 93.6 & 91.3 & 91.0 & 90.7 \\
\hline Histidine & 92.1 & 91.6 & 89.5 & 89.6 \\
\hline Isoleucine & 87.8 & 85.0 & 81.2 & 80.4 \\
\hline Leucine & 91.0 & 88.5 & 86.2 & 85.5 \\
\hline Lysine & 79.2 & 73.6 & 65.8 & 66.5 \\
\hline Methionine & 85.4 & 82.8 & 76.9 & 78.1 \\
\hline Phenylatanine & 92.0 & 91.1 & 88.4 & 87.6 \\
\hline Threonine & 87.0 & 83.6 & 80.9 & 80.1 \\
\hline Valine & 87.8 & 84.2 & 80.9 & 79.5 \\
\hline Nitrogen & 89.4 & 85.5 & 83.6 & 81.7 \\
\hline Dry matter. & 92.1 & 89.1 & 88.1 & 86.5 \\
\hline \multicolumn{5}{|l|}{ True availability } \\
\hline \multicolumn{5}{|l|}{ Amino acids } \\
\hline Arginine & 95.9 & 93.0 & 92.4 & 92.3 \\
\hline Histidine & $94 \cdot 3$ & $93 \cdot 5$ & 91.1 & 91.4 \\
\hline Isoleucine & 92.4 & 88.5 & 84.2 & 83.7 \\
\hline Leucine & 94.2 & 91.2 & 88.4 & 87.9 \\
\hline lysine & 84.9 & 78.1 & 69.9 & 70.9 \\
\hline Methionine & 90.4 & 86.8 & 80.4 & 81.9 \\
\hline Phenylalanine & 95.1 & 93.1 & 90.2 & 89.8 \\
\hline Threonine & 91.7 & 87.4 & 84.0 & 83.6 \\
\hline Valine & 92.6 & 88.0 & 84.0 & 82.9 \\
\hline Nitrogen & $93 \cdot 3$ & 88.6 & 86.2 & 84.6 \\
\hline
\end{tabular}

Mean of 8 determinations 


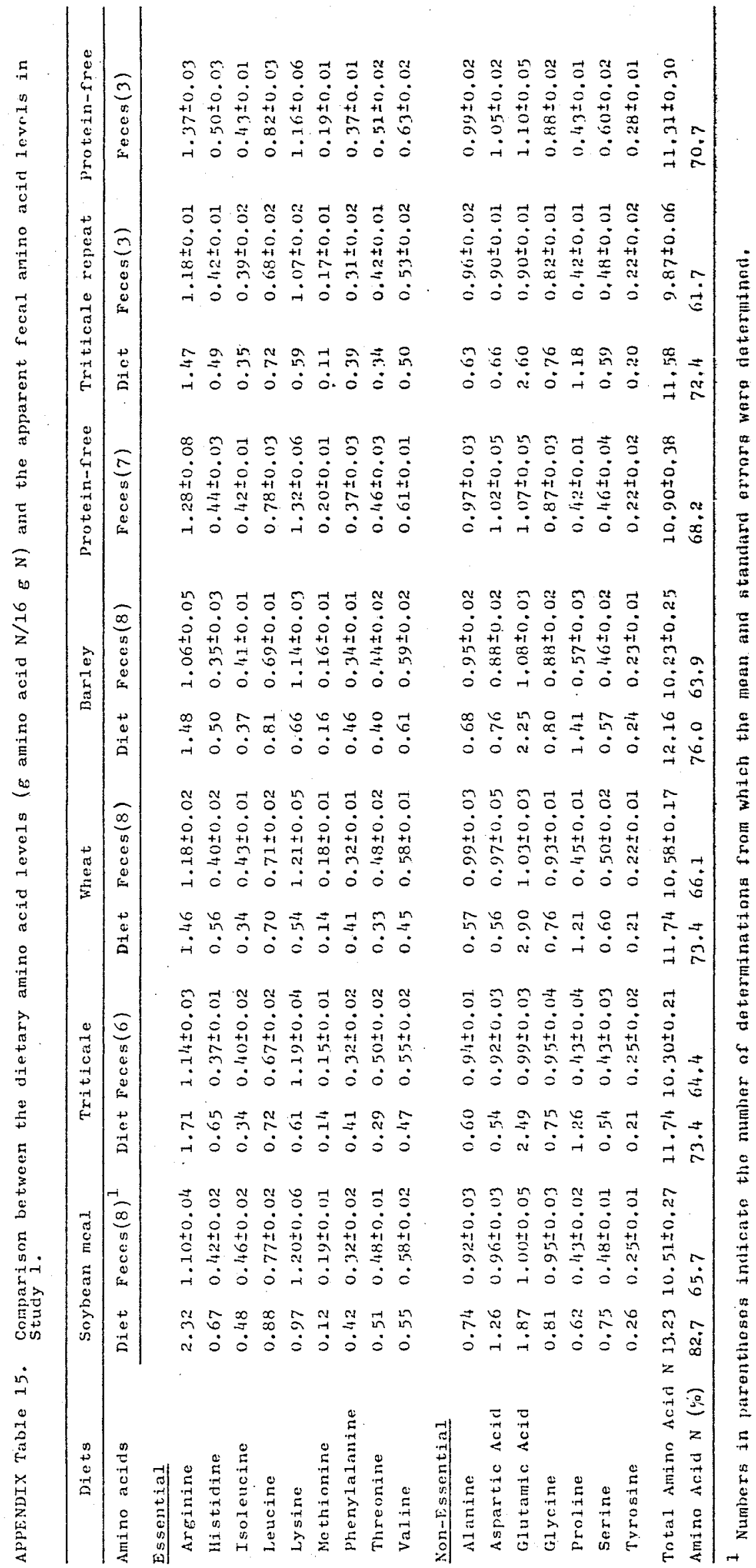




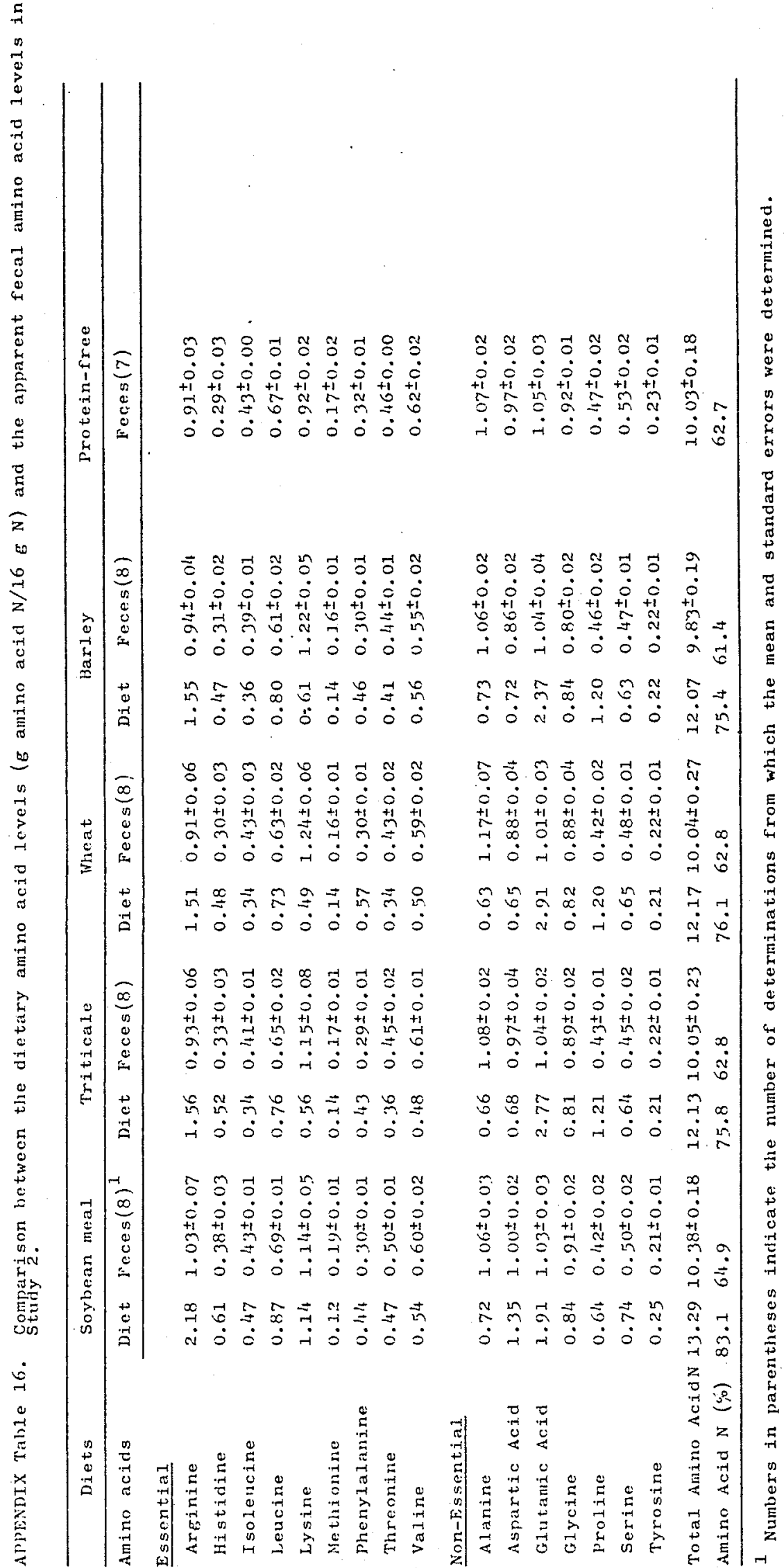

